\title{
Ticks and Tick-Borne Pathogens Associated with Dromedary Camels (Camelus dromedarius) in Northern Kenya
}

\author{
Dennis Getange ${ }^{1,2}$, Joel L. Bargul ${ }^{1,2, *}$, Esther Kanduma ${ }^{3}{ }^{\circ}$, Marisol Collins ${ }^{4}$, Boku Bodha ${ }^{5}$, Diba Denge ${ }^{5}$, \\ Tatenda Chiuya ${ }^{1}$, Naftaly Githaka ${ }^{6}$, Mario Younan ${ }^{7}$, Eric M. Fèvre $\left.{ }^{4,6}{ }^{(}\right)$, Lesley Bell-Sakyi ${ }^{4}(\mathbb{D}$ \\ and Jandouwe Villinger $1, *$ (i)
}

Citation: Getange, D.; Bargul, J.L.; Kanduma, E.; Collins, M.; Bodha, B.; Denge, D.; Chiuya, T.; Githaka, N.; Younan, M.; Fèvre, E.M.; et al. Ticks and Tick-Borne Pathogens Associated with Dromedary Camels (Camelus dromedarius) in Northern Kenya. Microorganisms 2021, 9, 1414. https://doi.org/10.3390/ microorganisms 9071414

Academic Editors: Chao-Nan Lin and Peck Toung Ooi

Received: 4 June 2021

Accepted: 22 June 2021

Published: 30 June 2021

Publisher's Note: MDPI stays neutral with regard to jurisdictional claims in published maps and institutional affiliations.

Copyright: (c) 2021 by the authors Licensee MDPI, Basel, Switzerland. This article is an open access article distributed under the terms and conditions of the Creative Commons Attribution (CC BY) license (https:/ / creativecommons.org/licenses/by/ $4.0 /)$.
1 International Centre of Insect Physiology and Ecology (icipe), Nairobi P.O. Box 30772-00100, Kenya; gdennoh89@gmail.com (D.G.); tatendachiuya@gmail.com (T.C.)

2 Department of Biochemistry, Jomo Kenyatta University of Agriculture and Technology, Nairobi P.O. Box 62000-00200, Kenya

3 Department of Biochemistry, School of Medicine, University of Nairobi, Nairobi P.O. Box 30197-00100, Kenya; ekanduma@uonbi.ac.ke

4 Institute of Infection, Veterinary and Ecological Sciences, University of Liverpool, Liverpool L3 5RF, UK; Marisol.Collins@liverpool.ac.uk (M.C.); Eric.Fevre@liverpool.ac.uk (E.M.F.);

L.Bell-Sakyi@liverpool.ac.uk (L.B.-S.)

5 Directorate of Veterinary Services, County Government of Marsabit, Marsabit P.O. Box 384-60500, Kenya; bokubodha@gmail.com (B.B.); dengediba@gmail.com (D.D.)

6 International Livestock Research Institute, Nairobi P.O. Box 30709-00100, Kenya; N.githaka@cgiar.org

7 Food and Agriculture Organization of the United Nations (FAO), Programme \& Operational Support to Syria Crisis, UN cross-border hub, Gaziantep 27010, Turkey; mario.younan@fao.org

* Correspondence: jbargul@icipe.org or jbargul@jkuat.ac.ke (J.L.B.); jandouwe@icipe.org (J.V.)

\begin{abstract}
Ticks and tick-borne pathogens (TBPs) are major constraints to camel health and production, yet epidemiological data on their diversity and impact on dromedary camels remain limited. We surveyed the diversity of ticks and TBPs associated with camels and co-grazing sheep at 12 sites in Marsabit County, northern Kenya. We screened blood and ticks (858 pools) from 296 camels and 77 sheep for bacterial and protozoan TBPs by high-resolution melting analysis and sequencing of PCR products. Hyalomma (75.7\%), Amblyomma (17.6\%) and Rhipicephalus (6.7\%) spp. ticks were morphologically identified and confirmed by molecular analyses. We detected TBP DNA in $80.1 \%$ of blood samples from 296 healthy camels. "Candidatus Anaplasma camelii", "Candidatus Ehrlichia regneryi" and Coxiella burnetii were detected in both camels and associated ticks, and Ehrlichia chaffeensis, Rickettsia africae, Rickettsia aeschlimannii and Coxiella endosymbionts were detected in camel ticks. We also detected Ehrlichia ruminantium, which is responsible for heartwater disease in ruminants, in Amblyomma ticks infesting camels and sheep and in sheep blood, indicating its endemicity in Marsabit. Our findings also suggest that camels and/or the ticks infesting them are disease reservoirs of zoonotic $Q$ fever (C. burnetii), ehrlichiosis (E. chaffeensis) and rickettsiosis $(R$. africae), which pose public health threats to pastoralist communities.
\end{abstract}

Keywords: dromedary camels; ticks; heartwater; zoonosis; tick-borne pathogens; Anaplasma; Coxiella; Ehrlichia; Rickettsia

\section{Introduction}

Kenya is home to over 3 million camels, representing about $6 \%$ of Africa's camel population [1,2]. In the northern parts of Kenya and the Horn of Africa, camel production is a major source of livelihood [1,3]. Since the 1960s, camel populations in this region have continued to increase despite numerous challenges brought about by climate change [2]. In response to increasingly frequent droughts, pastoralist communities that did not previously keep camels have started rearing them to supplement or replace income from cattle production [1]. In comparison with other ruminant livestock, camels are biologically and 
physiologically adapted to survive better in arid and semi-arid environments $[4,5]$. They provide a reliable source of meat and milk, even during dry seasons when production from other livestock species such as goats, sheep and cattle becomes insufficient [1]. Camels also play a role as beasts of burden [5].

Despite the economic importance and resilience of camels under harsh climatic conditions, camel production is constrained by pests, vector-borne diseases and parasites. Common haematophagous ectoparasites of camels, specifically in Marsabit County, northern Kenya, include biting flies (e.g., Tabanus, Stomoxys and Haematopota), the camel fly or camel ked Hippobosca camelina [6,7] and ticks, which are important disease vectors. While biting flies as mechanical vectors for trypanosomes in camels have been the subject of research for decades [7], very little is known about tick-borne pathogens circulating among camels in northern Kenya.

Tick-borne pathogens (TBPs) cause emerging and re-emerging diseases in Africa and beyond [8,9]. They are transmitted to animals and humans through tick bites and constitute major constraints to livestock production in Kenya [10]. Ticks are vectors of a wide range of pathogens, including viruses, bacteria and protozoa that can infect domestic and wild animals and humans [11-13]. These pathogens may cause bacterial diseases such as $Q$ fever, rickettsiosis, ehrlichiosis and anaplasmosis, protozoal diseases such as babesiosis and theileriosis and viral diseases such as Crimean-Congo hemorrhagic fever [11]. Ticks of the genus Hyalomma are most commonly associated with camels and are known vectors of Theileria, Babesia, Anaplasma, Rickettsia and Ehrlichia spp. [14-16]. Other genera of ticks infesting camels in Kenya include Rhipicephalus and Amblyomma [3,17].

In Kenya, most of the studies undertaken on ticks and TBPs of livestock have been limited to cattle, sheep and goats; camels remain understudied. Climate change, as well as the extensive movement of camels and other ruminant livestock across semi-arid counties and the northern borders of Kenya with neighbouring countries such as Somalia, Ethiopia and South Sudan, potentially contribute to shifts in the distribution of ticks and TBPs in the region. An Ehrlichia sp. with a DNA sequence close to E. ruminantium was found in ticks infesting camels in herds affected by an outbreak of heartwater-like disease in dromedary camels in the Moyale Constituency of Marsabit County; the disease occurred in most of North Kenya's camel keeping region and caused significant losses in adult animals in 2016 [18]. The present study, in which blood samples and ticks were collected from dromedary camels and co-herded sheep in Marsabit County, northern Kenya, was carried out as part of a wider investigation into the possible involvement of E. ruminantium and heartwater in this novel camel disease. Co-herded sheep were included in the wider study as indicators for the presence of E. ruminantium infection in an area because they develop high and long-lasting levels of serum antibodies following exposure $[19,20]$; the results from the serological investigation in camels and sheep will be presented in a separate publication. Here we report the results from the morphological identification of tick species infesting healthy camels and co-herded sheep, molecular detection and the characterization of various TBPs in the ticks and host blood. To the best of our knowledge, this is the first detailed molecular study on tick species infesting camels in Kenya and on TBPs in blood and ticks from these camels and their co-grazing sheep.

\section{Materials and Methods}

\subsection{Study Area}

The study was conducted in February 2020 in Marsabit County in northern Kenya, with an area of $\sim 66,923 \mathrm{~km}^{2}$ about $543 \mathrm{~km}$ north of Nairobi [21]. Marsabit County is located between longitudes $37^{\circ} 57^{\prime}$ and $39^{\circ} 21^{\prime}$ East and latitudes $02^{\circ} 45^{\prime}$ and $04^{\circ} 27^{\prime}$ North and borders Wajir and Isiolo Counties to the East, Turkana County to the West, Samburu County to the South and Ethiopia to the North. Marsabit County experiences extreme temperatures with minimum and maximum temperatures ranging from $16^{\circ} \mathrm{C}$ to $39^{\circ} \mathrm{C}$ [22]. The long wet season is from March to May, while the short wet season is from October to December [21]. Most of the County is located 300-900 m above sea level with an average 
annual rainfall ranging from below $150 \mathrm{~mm}$ to just over $1000 \mathrm{~mm}$. Marsabit County is home to pastoralist camel keepers who rely on mobile livestock production for their livelihoods.

Blood samples and ticks were collected from healthy dromedary camels and from co-grazing sheep at 12 sites: Laisamis, Korr, Hula Hula, Kamboe, Shegel, Burgabo, Gola, Misa, Funanyatta, Dabel, Yabalo and Bori (Figure 1). The wells located at these sites are important watering points for camels and other livestock.

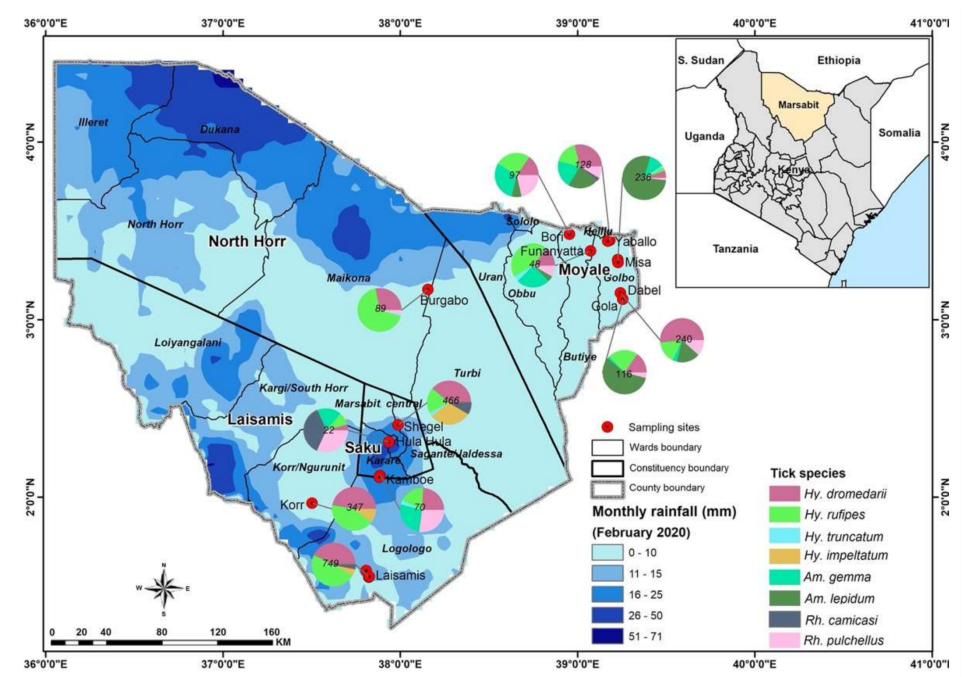

Figure 1. Sampling sites in Marsabit County, Kenya, showing the spatial distribution of tick species collected from camels and co-grazing sheep. Maps were created using the open-source software, QGIS v.3.10.6. Pie charts indicate numbers of ticks collected at sampling sites.

\subsection{Ethical Approval}

This study was undertaken in strict adherence to the experimental guidelines and procedures approved by the University of Nairobi Biosafety, Animal Use and Ethics Committee (REF: FVM BAUEC/2019/200) and Kenya's National Commission for Science, Technology and Innovation (REF: NACOSTI/P/19/72855/27325). Animals were handled carefully to cause minimum discomfort. The camel pastoralists were informed about the study and, thereafter, sampling of camels was conducted after receiving verbal consent as most herders were unable to read or write in addition to the language barriers that required translation by our field assistants selected from the community.

\subsection{Collection of Blood Samples and Ticks from Camels and Co-Herded Sheep}

Sample collection from 296 healthy camels and from 77 healthy co-herded sheep was conducted during the dry season from February 2020 to March 2020. Co-grazing sheep were sampled as sentinel animals for a parallel serological study of E. ruminantium antibody levels in this combined livestock cohort, as part of the overarching study investigating the role of heartwater and other TBPs in camel diseases in Kenya. Four millilitres of blood were collected from individual animals via jugular venepuncture using vacutainer needles (18 gauge) and EDTA vacutainer tubes. Blood samples were kept under cold chain $\left(4-10{ }^{\circ} \mathrm{C}\right.$ ) for up to $6 \mathrm{~h}$ before being preserved in liquid nitrogen for transportation to the Martin Lüscher Emerging Infectious Diseases (ML-EID) laboratory at icipe, Nairobi, for the molecular detection of TBPs.

Serrated forceps held firmly over the tick scuta and mouthparts were used to gently remove all visible ticks attached to the skin of sampled camels and sheep. Ticks were placed in cryovials and kept under cold chain $\left(4-10^{\circ} \mathrm{C}\right)$ for up to $2 \mathrm{~h}$ prior to preservation in liquid nitrogen for transportation to the ML-EID molecular biology laboratories for further analysis. 


\subsection{Morphological Identification of Ticks}

Ticks were identified to species level using taxonomic keys [23]. The morphological features used for tick identification included the colour and ornamentation of the scutum, shape, size and distribution of punctations and grooves and colour of legs. The ticks were staged under a Stemi 2000-C microscope (Zeiss, Oberkochen, Germany) and photographed using a digital microscope connected to an Axio-cam ERc 5s camera (Zeiss). Fully-engorged ticks were removed during tick identification and excluded from subsequent analysis to minimise vertebrate host DNA in nucleic acid extractions. Ticks were pooled into groups of one to eight individuals based on species, host, sampling site and date of collection.

\subsection{Extraction of DNA from Whole Ticks, Tick Leg Tissues and Blood}

Two representative adult ticks from each of the eight tick species identified from camels were selected for molecular confirmation of identity. Legs were plucked from individual ticks for genomic DNA extraction. For TBP screening, whole ticks were first frozen in liquid nitrogen before homogenising them in 1.5-mL microfuge tubes containing $150 \mathrm{mg}$ of $0.1-\mathrm{mm}$ and $750 \mathrm{mg}$ of 2.0-mm yttria-stabilised zirconium (YSZ) oxide beads (Glen Mills, Clifton, NJ, USA) and $100 \mu \mathrm{L}$ of $1 \times$ PBS using a Mini-Beadbeater-16 (BioSpec, Bartlesville, OK, USA) for 1 min. The ISOLATE II Genomic DNA extraction kit (Bioline, London, UK) was used to extract DNA from the leg tissues selected for tick identification and from homogenised whole tick and blood samples for pathogen screening following the manufacturer's instructions.

\subsection{Molecular Identification of Ticks}

In order to confirm findings of the morphological identification of tick species, we used the extracted tick genomic DNA in PCRs targeting fragments of the cytochrome oxidase subunit I (COI), 12S ribosomal (r)RNA and 16S rRNA genes (Table 1). The PCRs were performed in $10-\mu \mathrm{L}$ reaction volumes including $2 \mu \mathrm{L} 5 \times$ HOT FIREPol $^{\circledR}$ Blend Master Mix (Solis BioDyne, Tartu, Estonia), $0.5 \mu \mathrm{L}$ of $10 \mu \mathrm{M}$ forward and reverse primers (Table 1 ) and 25 ng of DNA template in a ProFlex PCR systems thermocycler (Applied Biosystems, Foster City, CA, USA). The following conditions were used for amplification: Initial denaturation at $95{ }^{\circ} \mathrm{C}$ for $15 \mathrm{~min}$ followed by 35 cycles of denaturation at $95^{\circ} \mathrm{C}$ for $30 \mathrm{~s}$, annealing (at $55{ }^{\circ} \mathrm{C}$ for $16 \mathrm{~S}$ rRNA and COI, at $48{ }^{\circ} \mathrm{C}$ for $12 \mathrm{~S}$ rRNA) for $30 \mathrm{~s}$, extension at $72{ }^{\circ} \mathrm{C}$ for $1 \mathrm{~min}$ and a final extension at $72{ }^{\circ} \mathrm{C}$ for $10 \mathrm{~min}$. Successful PCR amplification of target amplicons was determined by resolving $5 \mu \mathrm{L}$ of the PCR products by electrophoresis in $1.5 \%(w / v)$ agarose gels containing ethidium bromide and DNA fragments visualised under ultraviolet light using a Kodak Gel Logic 200 Imaging System (SPW Industrial, Laguna Hills, CA, USA). The remaining volumes of positive PCR amplicons were purified using ExoSAP-IT (Affymetrix, Santa Clara, CA, USA) according to the manufacturer's protocol and sequenced by Macrogen Inc. (Amsterdam, The Netherlands).

Table 1. Primers used for molecular identification of ticks and tick-borne pathogens.

\begin{tabular}{ccccc}
\hline Primer Name & Target Gene & Sequence (5'-3') & $\begin{array}{c}\text { Amplicon } \\
\text { Size (bp) }\end{array}$ & Reference \\
\hline $\begin{array}{c}\text { Tick COI F } \\
\text { Tick COI R }\end{array}$ & Tick COI & $\begin{array}{c}\text { ATTCAACCAATCATAAAGATATTGG } \\
\text { TAAACTTCTGGATGTCCAAAAAATCA }\end{array}$ & 658 & {$[24]$} \\
\hline $\begin{array}{c}\text { SR-J-14199F } \\
\text { SR-N-14594R }\end{array}$ & Tick 12S rRNA & $\begin{array}{c}\text { TACTATGTTACGACTTAT } \\
\text { AAACTAGGATTAGATACCC }\end{array}$ & \multirow{2}{*}{430} & {$[25]$} \\
\hline $\begin{array}{l}\text { Tick 16S } \\
\text { Tick 16S }\end{array}$ & Tick 16S rRNA & AATTGCTGTAGTATTTTGAC & \multirow{2}{*}{450} & {$[26]$} \\
\hline
\end{tabular}


Table 1. Cont.

\begin{tabular}{|c|c|c|c|c|}
\hline $\begin{array}{l}\text { Rick-F } \\
\text { Rick-R }\end{array}$ & Rickettsia 16S rRNA & $\begin{array}{l}\text { GAACGCTATCGGTATGCTTAACACA } \\
\text { CATCACTCACTCGGTATTGCTGGA }\end{array}$ & 364 & [27] \\
\hline $\begin{array}{l}120-2788 \\
120-3599\end{array}$ & Rickettsia отрВ & $\begin{array}{l}\text { AAACAATAATCAAGGTACTGT } \\
\text { TACTTCCGGTTACAGCAAAGT }\end{array}$ & 856 & [28] \\
\hline $\begin{array}{l}\text { Trans1 } \\
\text { Trans2 }\end{array}$ & Coxiella IS1111 & $\begin{array}{c}\text { TGGTATTCTTGCCGATGAC } \\
\text { GATCGTAACTGCTTAATAAACCG }\end{array}$ & 687 & [29] \\
\hline $\begin{array}{l}\text { Ehrlichia16S F } \\
\text { Ehrlichia16S R }\end{array}$ & Ehrlichia $16 \mathrm{~S}$ rRNA & $\begin{array}{l}\text { CGTAAAGGGCACGTAGGTGGACTA } \\
\text { CACCTCAGTGTCAGTATCGAACCA }\end{array}$ & 200 & [30] \\
\hline $\begin{array}{l}\text { PER1 } \\
\text { PER2 }\end{array}$ & Ehrlichia $16 \mathrm{~S}$ rRNA & $\begin{array}{l}\text { TTTATCGCTATTAGATGAGCCTATG } \\
\text { CTCTACACTAGGAATTCCGCTAT }\end{array}$ & 451 & [31] \\
\hline $\begin{array}{l}\text { EHR16SD } \\
\text { 1492R }\end{array}$ & Anaplasma/Ehrlichia 16S rRNA & $\begin{array}{c}\text { GGTACCYACAGAAGAAGTCC } \\
\text { GGTTACCTTGTTACGACTT }\end{array}$ & 1030 & {$[32,33]$} \\
\hline $\begin{array}{l}\text { AnaplasmaJV F } \\
\text { AnaplasmaJV R }\end{array}$ & Anaplasma 16S rRNA & $\begin{array}{l}\text { CGGTGGAGCATGTGGTTTAATTC } \\
\text { CGRCGTTGCAACCTATTGTAGTC }\end{array}$ & 300 & [34] \\
\hline $\begin{array}{l}\text { RLB F } \\
\text { RLB R }\end{array}$ & Theileria/Babesia 18S rRNA & $\begin{array}{c}\text { GAGGTAGTGACAAGAAATAACAATA } \\
\text { TCTTCGATCCCCTAACTTTC }\end{array}$ & $460-520 \mathrm{bp}$ & {$[35]$} \\
\hline
\end{tabular}

\subsection{Molecular Detection of TBPs}

In order to screen the DNA extracts of blood and ticks from camels and sheep for TBPs of the genera Anaplasma, Babesia, Coxiella, Ehrlichia, Rickettsia and Theileria, we conducted high-resolution melting (HRM) analysis of PCR products obtained using genus-specific primers (Table 1). The analysis was carried out in Rotor-Gene Q (QIAGEN, Hannover, Germany), Mic qPCR (Bio Molecular Systems, Upper Coomera, Queensland, Australia) and Quant Studio 3 Real-Time PCR System (Applied Biosystems, Foster City, CA, USA) thermocyclers. The primer pairs Ehrlichia16S and AnaplasmaJV were used to amplify 200-bp and 300-bp fragments of Ehrlichia and Anaplasma 16S rRNA genes, respectively. Samples with unique Ehrlichia and Anaplasma 16S rRNA amplicon HRM profiles were re-amplified using longer primers targeting 16S rRNA (PER1, PER2) for Ehrlichia [31] and EHR16SD-1492R for Anaplasma [32,33]. Theileria and Babesia were amplified using primers targeting the 18S ribosomal gene (RLB_F and RLB_R) [35]. Rickettsial 16S rRNA genes were amplified using primers Rick-F and Rick-R [27]. Rickettsia-positive samples were re-tested using rickettsial outer membrane protein B (oтpB) gene primers (28).

The PCRs were performed in $10-\mu \mathrm{L}$ volumes including $2 \mu \mathrm{L}$ HOT FIREPol ${ }^{\circledR}$ EvaGreen ${ }^{\circledR}$ HRM mix (Solis BioDyne, Tartu, Estonia), $0.5 \mu \mathrm{L}$ of $10 \mu \mathrm{M}$ forward and reverse primers and $25 \mathrm{ng}$ of template DNA. For no-template controls, $1 \mu \mathrm{L}$ nuclease-free water was used as a template. DNA samples of "Ca. Anaplasma camelii", "Ca. Ehrlichia regneryi", Theileria parva and Rickettsia africae from earlier studies $[6,18,36,37]$ were used as positive controls. The PCR cycling conditions included an initial enzyme activation at $95{ }^{\circ} \mathrm{C}$ for $15 \mathrm{~min}$; 10 cycles of denaturation at $94{ }^{\circ} \mathrm{C}$ for $20 \mathrm{~s}$, step-down annealing from $63.5^{\circ} \mathrm{C}$ to 53.5 ${ }^{\circ} \mathrm{C}$ (decreasing by $1{ }^{\circ} \mathrm{C}$ per cycle) for $25 \mathrm{~s}$ and extension at $72{ }^{\circ} \mathrm{C}$ for $30 \mathrm{~s} ; 25$ cycles of denaturation at $94{ }^{\circ} \mathrm{C}$ for $25 \mathrm{~s}$, annealing at 50 for $20 \mathrm{~s}$ and extension at $72{ }^{\circ} \mathrm{C}$ for 30 $\mathrm{s}$; and a final extension at $72{ }^{\circ} \mathrm{C}$ for $7 \mathrm{~min}$. A $3 \mathrm{~min}$ hold at $72{ }^{\circ} \mathrm{C}$ was included after PCR cycling before HRM analysis by gradually increasing the temperature from 75 to $90{ }^{\circ} \mathrm{C}$ with fluorescence acquisitions after $2 \mathrm{~s}$ at $0.1{ }^{\circ} \mathrm{C}$ increments [34]. All samples with unique melt profiles were purified with an ExoSAP-IT PCR Product Cleanup kit (Affymetrix, Santa Clara, CA, USA) and submitted for Sanger sequencing by Macrogen (Amsterdam, The Netherlands). Chromatogram files were imported into the Geneious Prime software v. 2020.2.2 (created by Biomatters, Auckland, New Zealand) in which they were trimmed, edited and aligned to generate consensus sequences. 


\subsection{Phylogenetic Analysis}

Nucleotide sequences obtained in this study were queried against known sequences in the GenBank nr database (http:/ / www.ncbi.nlm.nih.gov/, accessed on 15 May 2021) using BLAST to confirm their identity and relation to existing deposited sequences [38]. Study sequences were then aligned with related tick or pathogen sequences available in the GenBank nr database using the MAFFT plugin in Geneious Prime software version 2020.2.2 [39]. Maximum-likelihood phylogenies were constructed using PhyML v. 3.0 with automatic model selection based on the Akaike information criterion. Tree topologies were estimated over 1000 bootstrap replicates with the nearest neighbour interchange improvements [40]. Phylogenetic trees were visualised using FigTree v. 1.4.4 [41].

\subsection{Estimation of Tick Infection Rates}

Estimated minimum infection rates (MIRs) of each of the TBPs obtained for each tick species were calculated as the number of positive pools per total number of ticks of that species tested $\times 100$, with a conservative assumption that only one tick is positive per pathogen-positive pool.

\section{Results}

\subsection{Morphological and Molecular Identification of Ticks}

A total of 2610 adult ticks removed from camels were morphologically identified as Hyalomma dromedarii, Hyalomma rufipes, Hyalomma impeltatum, Hyalomma truncatum, Amblyomma lepidum, Amblyomma gemma, Rhipicephalus pulchellus and Rhipicephalus camicasi. Hyalomma was the most prevalent genus and comprised three quarters (75.7\%) of all adult ticks collected from camels, followed by Amblyomma (17.6\%) and Rhipicephalus (6.7\%). Tick infestation was low in sheep, from which we collected 86 adult ticks and identified them as Rh. camicasi, Am. gemma, Am. lepidum, Rh. pulchellus and Hy. rufipes. Rhipicephalus (53.5\%) was the dominant genus sampled from sheep, followed by Amblyomma (45.4\%) and Hyalomma (1.2\%). Figure 1 shows the total numbers of ticks and the proportions of each species collected at each sampling site. Table 2 summarises the number of tick species collected from camels and co-herded sheep in northern Kenya. Photomicrographs of representative specimens of the eight tick species identified are shown in Figure 2.

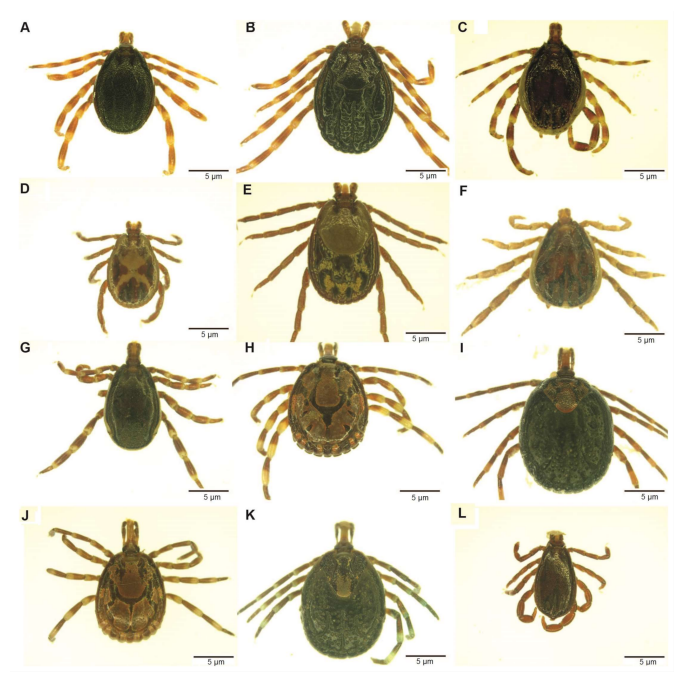

Figure 2. Images of adults of tick species collected from camels in northern Kenya. (A) Hyalomma rufipes male; (B) Hy. rufipes, female; (C) Hyalomma impeltatum, male; (D) Rhipicephalus pulchellus, male; (E) Rh. pulchellus, female; (F) Hyalomma dromedarii, male; (G) Hyalomma truncatum, male; (H) Amblyomma lepidum, male; (I) Am. lepidum, female; (J) Amblyomma gemma, male; (K) Am. gemma, female; (L) Rhipicephalus camicasi, male. The images were staged under a Stemi 2000-C microscope (Zeiss, Oberkochen, Germany) after thawing from liquid nitrogen and photographed using a digital microscope connected to an Axio-cam ERc 5s camera (Zeiss). 
Table 2. Tick species collected from camels and co-herded sheep in Marsabit, Kenya, in February2020 to March 2020.

\begin{tabular}{|c|c|c|c|c|c|c|c|c|c|c|}
\hline \multirow[b]{2}{*}{ Species } & \multicolumn{5}{|c|}{ From 296 Camels } & \multicolumn{5}{|c|}{ From 77 Co-Herded Sheep } \\
\hline & Male & Female & $\begin{array}{l}\text { No. of } \\
\text { Pools }\end{array}$ & $\begin{array}{l}\text { No. of } \\
\text { Ticks }\end{array}$ & $\begin{array}{c}\text { Percent } \\
(\%)\end{array}$ & Male & Female & $\begin{array}{l}\text { No. of } \\
\text { Pools }\end{array}$ & $\begin{array}{l}\text { No. of } \\
\text { Ticks }\end{array}$ & $\begin{array}{c}\text { Percent } \\
(\%)\end{array}$ \\
\hline Amblyomma gemma & 80 & 49 & 87 & 129 & 4.95 & 11 & 4 & 12 & 15 & 17.44 \\
\hline Amblyomma lepidum & 186 & 144 & 120 & 330 & 12.64 & 20 & 4 & 12 & 24 & 27.91 \\
\hline Hyalomma dromedarii & 624 & 295 & 233 & 919 & 35.21 & & & & & \\
\hline $\begin{array}{l}\text { Hyalomma } \\
\text { rufipes }\end{array}$ & 557 & 253 & 251 & 810 & 31.03 & 1 & & 1 & 1 & 1.16 \\
\hline Hyalomma truncatum & 19 & 6 & 12 & 25 & 0.96 & & & & & \\
\hline Hyalomma impeltatum & 153 & 68 & 44 & 221 & 8.47 & & & & & \\
\hline Rhipicephalus pulchellus & 73 & 31 & 66 & 104 & 3.98 & 1 & & 1 & 1 & 1.16 \\
\hline Rhipicephalus camicasi & 30 & 42 & 24 & 72 & 2.76 & 22 & 23 & 22 & 45 & 52.33 \\
\hline Total & 1734 & 876 & 858 & 2610 & & 55 & 31 & 48 & 86 & \\
\hline
\end{tabular}

BLASTn analysis of Am. gemma, Am. lepidum, Rh. camicasi, Rh. pulchellus, Hy. dromedarii, Hy. impeltatum, Hy. truncatum and Hy. rufipes sequences obtained in this study showed identities ranging from 99 to $100 \%$ with reference sequences from the GenBank nr database (Table S1). Molecular identification based on partial 12S rRNA, 16S rRNA and COI gene sequences obtained from 15 representative samples was consistent with morphological identification and confirmed the wide diversity of tick species collected from camels (Figure 3). The 12S rRNA and 16S rRNA molecular identification was more informative due to more consistent amplification as we were able to amplify COI sequences from only four of the tick samples. All tick sequences obtained in this study have been deposited in GenBank (COI gene accessions MT896151-MT896154; 12S rRNA gene accessions MT895851-MT895865; 16S rRNA gene accessions MT895169-MT895181).

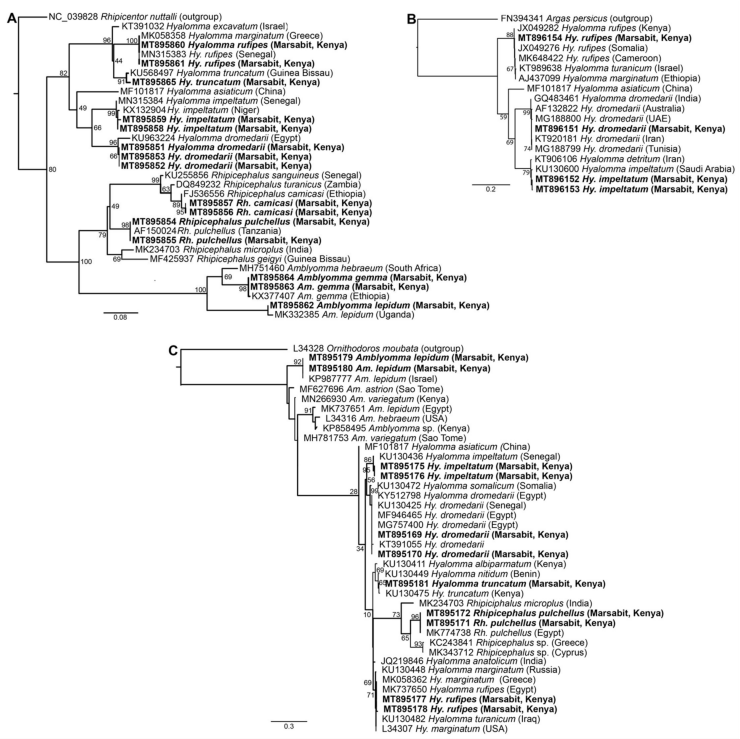

Figure 3. Maximum likelihood phylogenetic trees of representative gene sequences from samples of ticks collected from camels in Northern Kenya. (A) 12S rRNA, (B) COI mitochondrial and (C) $16 \mathrm{~S}$ rRNA gene sequences. Sequences obtained from this study, with their GenBank accession numbers, are noted in bold. Bootstrap values at the major nodes are of percentage agreement among 1000 bootstrap replicates. The branch length scale represents substitutions per site. Trees are rooted to outgroup sequences (indicated in brackets; top sequence of each tree).

\subsection{Tick-Borne Pathogens Detected in Camel and Sheep Blood}

We detected tick-borne pathogens with distinct HRM profiles (Figure 4) that shared $\geq 99 \%$ identity with sequences from other recognised TBP species in GenBank (Table 3). Three bacterial species, "Candidatus Anaplasma camelii", "Candidatus Ehrlichia regneryi" 
and Coxiella burnetii, were detected in camels using genus-specific primers, with infection rates of $78.7 \%, 14.5 \%$ and $3.4 \%$, respectively (Table 3). "Candidatus A. camelii" 16S rRNA (1030 bp), "Ca. E. regneryi" $16 \mathrm{~S}$ rRNA (451 bp) and C. burnetii transposon-like IS1111 (687 bp) gene sequences were successfully amplified from camel blood and characterised by sequencing. The C. burnetii sequences (GenBank accessions MT900497-MT900501,) shared 100\% identity with C. burnetii reference sequences with GenBank accessions DQ379976, KT954146 and MT268529. Rickettsia, Theileria and Babesia pathogens were not detected in the blood collected from camels. In blood collected from co-herded sheep, we detected $E$. ruminantium (100\% nucleotide sequence identity to E. ruminantium strain Welgevonden GenBank accession NR_074155), Ehrlichia chaffeensis (100\% identity to E. chaffeensis strain Arkansas, GenBank accession NR_074500), Theileria ovis (100\% identity to T. ovis GenBank accession MN712508) and Anaplasma ovis (100\% identity to A. ovis, GenBank accession MG869525) (Table 4, Figure 5A,B). Anaplasma ovis and T. ovis were not detected in camels.
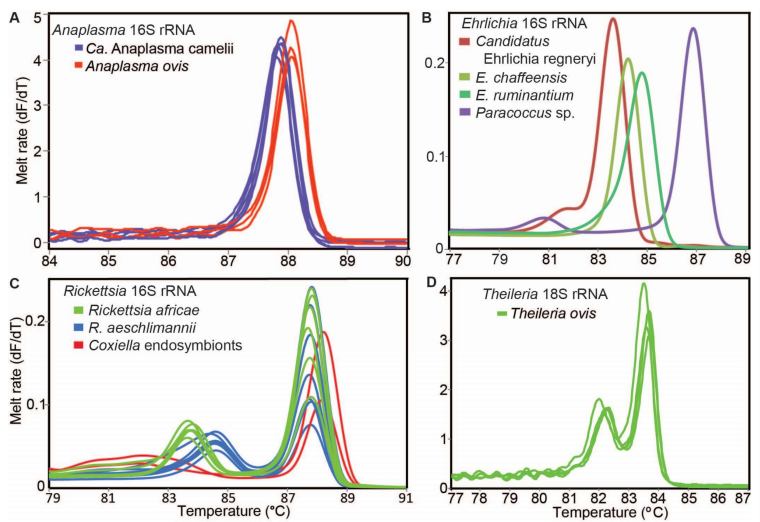

Figure 4. Representative melt rate profiles of tick-borne pathogens in tick samples collected from camels and sheep in northern Kenya. PCR-amplicon melt rates are represented as change in fluorescence with increasing temperature (dF/dT) of (A) Anaplasma 16S rRNA, (B) Ehrlichia 16S rRNA, (C) Rickettsia 16S rRNA and (D) Theileria 18S rRNA gene amplicons.

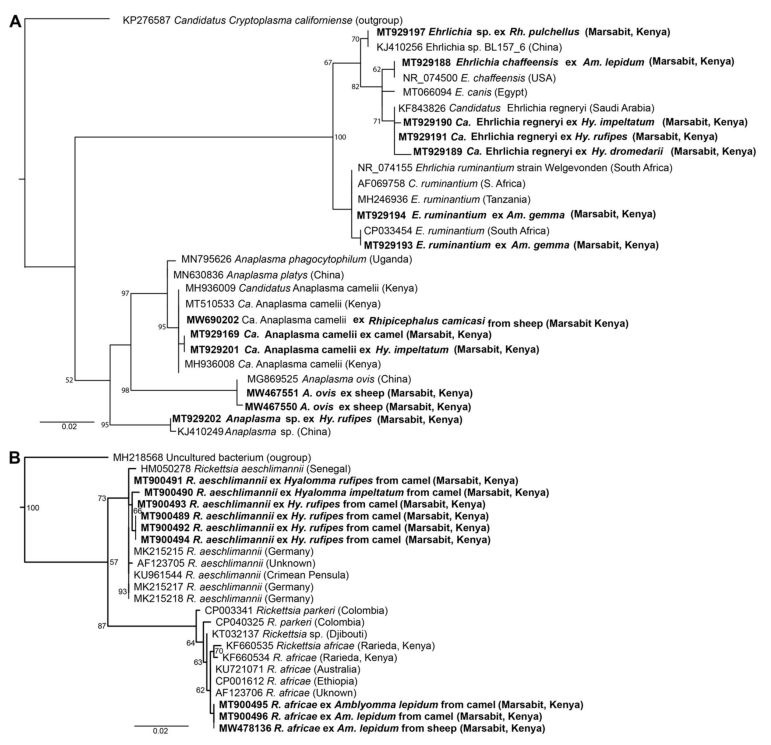

Figure 5. Maximum likelihood phylogenetic trees of (A) 1030-bp Anaplasma spp. and 451-bp Ehrlichia spp. 16S rRNA sequences and (B) 857-bp Rickettsia spp. ompB sequences. Sequences amplified from blood and ticks infesting camels in northern Kenya in this study are indicated in bold. Bootstrap values at the major nodes are of percentage agreement among 1000 bootstrap replicates. The branch length scale represents substitutions per site. Trees are rooted to outgroup sequences (indicated in brackets; top sequence of each tree). 
Table 3. Minimum infection rates for tick-borne pathogens (TBPs) identified in ticks and blood samples collected from camels in Marsabit, Kenya (February 2020 to March 2020).

\begin{tabular}{|c|c|c|c|c|c|c|c|c|c|c|c|c|}
\hline \multirow{2}{*}{$\begin{array}{c}\text { Bacterial } \\
\text { Species } \\
\text { (Target Gene) }\end{array}$} & \multicolumn{8}{|c|}{ TBP Detection in Ticks-Number of Positive Pools (Minimum Infection Rate) } & \multirow{2}{*}{$\begin{array}{l}\text { Camels with TBPs } \\
\text { (Infection Rate) }\end{array}$} & \multicolumn{2}{|c|}{ GenBank Accessions } & \multirow{2}{*}{$\begin{array}{l}\text { Nucleotide } \\
\text { Sequence } \\
\text { Identity }\end{array}$} \\
\hline & $\begin{array}{c}\text { Hy. } \\
\text { dromedarii }\end{array}$ & $\begin{array}{l}\text { Hy. } \\
\text { rufipes }\end{array}$ & $\begin{array}{c}\mathrm{Hy} . \\
\text { impeltatum }\end{array}$ & $\begin{array}{c}\text { Hy. } \\
\text { truncatum }\end{array}$ & $\begin{array}{c}\text { Am. } \\
\text { gemma }\end{array}$ & $\begin{array}{c}\text { Am. } \\
\text { lepidum }\end{array}$ & $\begin{array}{c}\mathrm{Rh} . \\
\text { camicasi }\end{array}$ & $\begin{array}{c}\text { Rh. } \\
\text { pulchellus }\end{array}$ & & $\begin{array}{c}\text { Study } \\
\text { Sequences }\end{array}$ & $\begin{array}{l}\text { Reference GenBank } \\
\text { Accessions }\end{array}$ & \\
\hline $\begin{array}{c}\text { No. of } \\
\text { individuals }\end{array}$ & $\begin{array}{l}919 \\
\text { ticks }\end{array}$ & $\begin{array}{l}810 \\
\text { ticks }\end{array}$ & $\begin{array}{l}221 \\
\text { ticks }\end{array}$ & $\begin{array}{l}25 \\
\text { ticks }\end{array}$ & $\begin{array}{l}129 \\
\text { ticks }\end{array}$ & $\begin{array}{l}330 \\
\text { ticks }\end{array}$ & $\begin{array}{l}72 \\
\text { ticks }\end{array}$ & $\begin{array}{l}104 \\
\text { ticks }\end{array}$ & $\begin{array}{c}296 \\
\text { camels }\end{array}$ & & & \\
\hline Number of tick pools & 254 & 251 & 44 & 12 & 87 & 120 & 24 & 66 & & & & \\
\hline $\begin{array}{c}\text { Ehrlichia } \\
\text { ruminantium(16S rRNA) }\end{array}$ & & & & & $\begin{array}{c}16 \\
(12.40 \%)\end{array}$ & $\begin{array}{c}17 \\
(5.15 \%)\end{array}$ & & & & $\begin{array}{l}\text { MT929193- } \\
\text { MT929195 }\end{array}$ & $\begin{array}{c}\text { NR_074155, KU721071, } \\
\text { CP001612 }\end{array}$ & $100 \%$ \\
\hline $\begin{array}{l}\text { Ca. Ehrlichia } \\
\text { regneryi } \\
\text { (16S rRNA) }\end{array}$ & $\begin{array}{c}22 \\
(2.39 \%)\end{array}$ & $\begin{array}{c}46 \\
(5.68 \%)\end{array}$ & $\begin{array}{c}6 \\
(2.72 \%)\end{array}$ & & & & & & $\begin{array}{c}43 \\
(14.53 \%)\end{array}$ & $\begin{array}{l}\text { MT929189- } \\
\text { MT929192 }\end{array}$ & KF843826 & $100 \%$ \\
\hline $\begin{array}{l}\text { Ehrlichia chaffeensis } \\
\text { (16S rRNA) }\end{array}$ & & & & & & $\begin{array}{c}2 \\
(0.61 \%) \\
\end{array}$ & & & & MT929188 & $\begin{array}{l}\text { NR_074500, NR_074501, } \\
\text { CP007473-СP007480 }\end{array}$ & $100 \%$ \\
\hline $\begin{array}{l}\text { Ehrlichia sp. } \\
\text { (16S rRNA) }\end{array}$ & & $\begin{array}{c}1 \\
(0.12 \%) \\
\end{array}$ & & & $\begin{array}{c}1 \\
(0.78 \%) \\
\end{array}$ & & $\begin{array}{c}3 \\
(4.17 \%) \\
\end{array}$ & $\begin{array}{c}18 \\
(17.31 \%) \\
\end{array}$ & & $\begin{array}{l}\text { MT929196- } \\
\text { MT929197 }\end{array}$ & MN726921, KJ410256 & $100 \%$ \\
\hline $\begin{array}{c}\text { Candidatus Anaplasma } \\
\text { camelii } \\
\text { (16S rRNA) }\end{array}$ & $\begin{array}{c}25 \\
(2.72 \%)\end{array}$ & $\begin{array}{c}27 \\
(3.33 \%)\end{array}$ & $\begin{array}{c}6 \\
(2.72 \%)\end{array}$ & $\begin{array}{c}1 \\
(4 \%)\end{array}$ & $\begin{array}{c}11 \\
(8.53 \%)\end{array}$ & $\begin{array}{c}20 \\
(6.06 \%)\end{array}$ & $\begin{array}{c}6 \\
(8.33 \%)\end{array}$ & $\begin{array}{c}7 \\
(6.73 \%)\end{array}$ & $\begin{array}{c}233 \\
(78.72 \%)\end{array}$ & $\begin{array}{l}\text { MT929199- } \\
\text { MT929201, } \\
\text { MT929169- } \\
\text { MT929177 }\end{array}$ & MT510533, MK388297 & $100 \%$ \\
\hline $\begin{array}{l}\text { Anaplasma sp. } \\
\text { (16S rRNA) }\end{array}$ & & $\begin{array}{c}1 \\
(0.12 \%)\end{array}$ & & & & & & & & MT929202 & KJ410248, KJ410249 & $100 \%$ \\
\hline $\begin{array}{c}\text { Rickettsia } \\
\text { aeschlimannii(ompB) }\end{array}$ & $\begin{array}{c}3 \\
(0.33 \%)\end{array}$ & $\begin{array}{c}87 \\
(1.07 \%)\end{array}$ & $\begin{array}{c}6 \\
(2.72 \%)\end{array}$ & $\begin{array}{c}1 \\
(4.00 \%)\end{array}$ & & & & $\begin{array}{c}5 \\
(4.81 \%)\end{array}$ & & $\begin{array}{l}\text { MT900489- } \\
\text { MT900494 }\end{array}$ & MK215215-MK215218 & $100 \%$ \\
\hline $\begin{array}{l}\text { Coxiella burnetii } \\
\text { (IS1111) }\end{array}$ & $\begin{array}{c}11 \\
(1.20 \%)\end{array}$ & $\begin{array}{c}12 \\
(1.50 \%)\end{array}$ & & & & & & $\begin{array}{c}5 \\
(4.81 \%)\end{array}$ & $\begin{array}{c}10 \\
(3.38 \%)\end{array}$ & $\begin{array}{l}\text { MT900497- } \\
\text { MT900501 }\end{array}$ & $\begin{array}{c}\text { DQ379976, KT954146, } \\
\text { MT268529 }\end{array}$ & $100 \%$ \\
\hline $\begin{array}{c}\text { Coxiella } \\
\text { endo- } \\
\text { symbiont } \\
(16 \mathrm{~S} \text { rRNA) }\end{array}$ & & & & & $\begin{array}{c}12 \\
(9.30 \%)\end{array}$ & $\begin{array}{c}16 \\
(22.22 \%)\end{array}$ & & $\begin{array}{c}6 \\
(5.77 \%)\end{array}$ & & $\begin{array}{l}\text { MW541904- } \\
\text { MW541911 }\end{array}$ & $\begin{array}{l}\text { EU143670, JX846589, } \\
\text { MK026405 }\end{array}$ & $98-100 \%$ \\
\hline $\begin{array}{l}\text { Paracoccus sp. } \\
\text { (16S rRNA) }^{1}\end{array}$ & $\begin{array}{c}2 \\
(0.22 \%)\end{array}$ & $\begin{array}{c}8 \\
(1.00 \%)\end{array}$ & $\begin{array}{c}2 \\
(0.90 \%)\end{array}$ & $\begin{array}{c}1 \\
(4.00 \%)\end{array}$ & $\begin{array}{c}1 \\
(0.78 \%)\end{array}$ & & & $\begin{array}{c}3 \\
(2.88 \%)\end{array}$ & & 2 & КР003988 & $99 \%$ \\
\hline
\end{tabular}

${ }^{1}$ amplified using the primer pair Ehrlichia16S F and Ehrlichia16S R (29) (Table 1). 
Table 4. Minimum infection rates for tick-borne pathogens (TBPs) identified in ticks and blood samples collected from sheep in Marsabit, Kenya (February 2020 to March 2020).

\begin{tabular}{|c|c|c|c|c|c|c|c|c|c|}
\hline \multirow{2}{*}{$\begin{array}{c}\text { Bacterial } \\
\text { Species } \\
\text { (Target Gene) }\end{array}$} & \multicolumn{5}{|c|}{$\begin{array}{c}\text { TBP Detection in Ticks-Number of Positive Pools } \\
\text { (Minimum Infection Rate) }\end{array}$} & \multirow{2}{*}{$\begin{array}{c}\text { Sheep with } \\
\text { TBPs } \\
\text { (Infection Rate) }\end{array}$} & \multicolumn{2}{|c|}{ GenBank Accessions } & \multirow{2}{*}{$\begin{array}{c}\text { Nucleotide } \\
\text { Sequence } \\
\text { Identity }\end{array}$} \\
\hline & $\begin{array}{l}\text { Hy. } \\
\text { rufipes }\end{array}$ & $\begin{array}{c}\text { Am. } \\
\text { gemma }\end{array}$ & $\begin{array}{c}\text { Am. } \\
\text { lepidum }\end{array}$ & $\begin{array}{c}R h . \\
\text { camicasi }\end{array}$ & $\begin{array}{c}\text { Rh. } \\
\text { pulchellus }\end{array}$ & & $\begin{array}{c}\text { Study } \\
\text { Sequences }\end{array}$ & $\begin{array}{c}\text { Reference } \\
\text { GenBank } \\
\text { Accessions }\end{array}$ & \\
\hline $\begin{array}{c}\text { No. of } \\
\text { individuals }\end{array}$ & 1 tick & 14 ticks & 24 ticks & 45 ticks & 1 tick & 77 sheep & & & \\
\hline $\begin{array}{l}\text { No. of tick } \\
\text { pools }\end{array}$ & 1 & 12 & 12 & 22 & 1 & & & & \\
\hline $\begin{array}{l}\text { Ehrlichia } \\
\text { ruminantium } \\
\text { (16S rRNA) }\end{array}$ & & $2(14.29 \%)$ & $1(4.17 \%)$ & & & $1(1.30 \%)$ & MW467546 & $\begin{array}{c}\text { NR_074155, } \\
\text { MH246936, } \\
\text { U03776 }\end{array}$ & $100 \%$ \\
\hline $\begin{array}{c}\text { Ehrlichia } \\
\text { chaffeensis } \\
\text { (16S rRNA) }\end{array}$ & & & & & & $2(2.60 \%)$ & & NR_074501 & $100 \%$ \\
\hline $\begin{array}{l}\text { Anaplasma ovis } \\
\text { (16S rRNA) }\end{array}$ & & $2(14.29 \%)$ & $2(8.33 \%)$ & $7(15.56 \%)$ & $1(100 \%)$ & $68(88.31 \%)$ & $\begin{array}{l}\text { MW467547- } \\
\text { MW467552 }\end{array}$ & MG869525 & $100 \%$ \\
\hline $\begin{array}{l}\text { Rickettsia } \\
\text { africae } \\
(\text { ompB) }\end{array}$ & & $2(14.29 \%)$ & $4(16.67 \%)$ & & & & $\begin{array}{l}\text { MW478135- } \\
\text { MW478138 }\end{array}$ & KU721071 & $100 \%$ \\
\hline $\begin{array}{c}\text { Theileria ovis } \\
\text { (18S rRNA) }\end{array}$ & & & & $1(2.22 \%)$ & & $62(80.52 \%)$ & $\begin{array}{l}\text { MW467555- } \\
\text { MW467561 }\end{array}$ & $\begin{array}{l}\text { MN712508, } \\
\text { KX273858, } \\
\text { MG738321 }\end{array}$ & $100 \%$ \\
\hline
\end{tabular}




\subsection{Tick-Borne Pathogens and Endosymbionts Detected in Ticks}

We screened 858 tick pools from camels for Ehrlichia, Anaplasma, Rickettsia, Coxiella, Babesia and Theileria species. In ticks sampled from camels, we detected 451-bp 16S rRNA gene sequences of E. ruminantium, "Ca. E. regneryi", E. chaffeensis and an Ehrlichia sp. Sequence similarities to reference sequences and to TBPs identified in camel herds of the study region in 2016 are indicated in Table 3 and the maximum likelihood phylogenetic relationships are shown in Figure 5A. We detected an E. ruminantium sequence, identical to that found in sheep blood, in Am. gemma and Am. lepidum; "Ca. E. regneryi" was detected in all three species of Hyalomma; E. chaffeensis (100\% identity to E. chaffeensis strain Arkansas, GenBank accession NR_074500) was detected in Am. lepidum ticks; and an Ehrlichia sp. (100\% identity to Ehrlichia sp. MN726921, detected in a Hyalomma anatolicum tick in Pakistan) was detected in Hy. rufipes, Am. gemma, Rh. camicasi and Rh. pulchellus ticks from different camels in different herds. Additionally, using the primer pair Ehrlichia16S F and Ehrlichia 16S R, we amplified short (163 bp) sequences identified as Paracoccus sp. (99\% identity to Paracoccus sp. BRM2, GenBank accession KP003988, isolated from Tunisian phosphogypsum) in Amblyomma, Hyalomma and Rhipicephalus spp. collected from camels at five different sites (Table S3).

We detected identical C. burnetii sequences in camel blood and Hy. dromedarii, Hy. rufipes and Rh. pulchellus ticks. Additionally, we detected Coxiella endosymbionts in Am. gemma, Am. lepidum and Rh. pulchellus ticks using the Rick16S primers.

We detected "Ca. Anaplasma camelii" in all the species of Hyalomma, Amblyomma and Rhipicephalus spp. identified in this study; an Anaplasma sp. sequence in Hy. rufipes; Rickettsia aeschlimannii in Hyalomma and Rhipicephalus spp.; and Rickettsia africae in the two Amblyomma spp. identified in this study as shown in Table 3 and Figure 5B. In ticks sampled from sheep, we detected E. ruminantium (100\% identity to E. ruminantium strain Welgevonden NR_074155) in Amblyomma spp.; R. africae in Amblyomma spp.; Theileria ovis in Rhipicephalus spp.; Anaplasma ovis in Amblyomma and Rhipicephalus spp.; and "Ca. A. camelii" in Rh. camicasi (Table 4). The distributions of ticks and pathogens according to the sampling sites are shown in Table S2. We detected three pathogens, "Ca. Anaplasma camelii" $(21.3 \%)$, "Ca. Ehrlichia regneryi" (3.4\%) and C. burnetii $(0.3 \%)$, in both blood and ticks from the same individual camels. Among sheep, we detected E. ruminantium, A. ovis and T. ovis in both ticks and blood from the same individual sheep (Table S3).

All sequences generated in this study have been submitted to GenBank under the following accessions: MT900489-MT900496 and MW478135-MW478138 for R. aeschlimannii and R. africae, MT900497-MT900501 for C. burnetii, MT929189-MT929192 for "Ca. E. regneryi", MT929193-MT929195 and MW467546 for E. ruminantium, MT929188 for E. chaffeensis, MT929196-MT929197 for Ehrlichia sp., MT929199-MT929201, MT929169-MT929177 and MW690202 for "Ca. A. camelii", MT929202 for Anaplasma sp., MW541904-MW541911 for Coxiella endosymbionts, MW467555-MW467561 for T. ovis and MW467547-MW467552 for A. ovis. The maximum likelihood phylogenies of all pathogen sequences obtained in this study along with sequences from previously characterized and closely-related TBPs from GenBank are represented in Figure 5.

\section{Discussion}

This study provides critical insight on the diversity and abundance of tick species on camels and co-herded sheep in northern Kenya and the TBPs in ticks and blood from these animals. Tick species on camels identified in this study confirm earlier reports on camel ticks in North Kenya [17]. We also report for the first time that Hy. impeltatum ticks parasitise camels in Kenya. Notably, we found a diversity of ticks and tick-borne microorganisms associated with camel herds distinct from those recently identified on cattle in western Kenya [42]. We identified four TBPs, R. africae (in sheep ticks), E. ruminantium (in camel ticks, sheep ticks and sheep blood), E. chaffeensis (in camel ticks and sheep blood) and C. burnetii (in camel ticks and camel blood), that are of major economic, animal health and/or human health importance $[11,13,43]$. Information on tick species diversity, ecology 
and distribution will help improve the understanding of disease dynamics [44] and is a prerequisite for any future prophylaxis or control measures.

\subsection{Species Diversity of Ticks Associated with Camels and Co-Herded Sheep in Northern Kenya}

We identified eight epidemiologically-important tick species from three different genera, Hyalomma, Amblyomma and Rhipicephalus, parasitising camels and co-herded sheep. These tick genera have been reported to infest a broad range of vertebrate host species and transmit several important pathogens, including viruses, bacteria and protozoa of medical and veterinary importance $[12,45]$.

The most prevalent tick species sampled from camels were Hy. dromedarii $(35.21 \%)$ and Hy. rufipes (31.03\%). Hyalomma dromedarii is considered to be the main tick species parasitising dromedary camels $[16,17,46]$ and is the principal vector of Theileria spp. of camels in Egypt [47]. Hyalomma dromedarii may play a role in the epidemiology or transmission of emerging and re-emerging diseases such as rickettsioses [48-50], viruses such as Crimean-Congo haemorrhagic fever virus (CCHFV) and C. burnetii (responsible for zoonotic $\mathrm{Q}$ fever) [51,52]. A high prevalence of Hy. dromedarii has been reported in camels found in arid and hyper-arid regions of Kenya [17], Saudi Arabia, Sudan, Egypt, Iran and Tunisia, with infestation rates ranging between $49 \%$ and $89 \%$ [15,16,45,53-55]. This tick can also infest other livestock, such as cattle, goats, sheep and horses [56,57], though we did not find this species on sheep co-herded with camels in the present study. Hyalomma rufipes, found on both camels and sheep, is known to be a vector of CCHFV as well as of R. aeschlimannii, Anaplasma marginale, Rickettsia conorii and Babesia occultans [58-60]. We also found, for the first time in Kenyan camels, Hy. impeltatum, which has previously been found on dromedary camels in Iran and northern Sudan [46,55,57]. Hyalomma impeltatum is known to have a wide range of animal hosts including buffalo, cattle and sheep $[16,61]$ and has the potential to transmit CCHFV [62].

We found Am. lepidum and Am. gemma ticks on both camels and sheep. The economic importance of Amblyomma spp. ticks has long been recognised due to their ability to transmit multiple diseases to humans and animals [11]. They are the major vectors of $E$. ruminantium, which is the causative agent of heartwater disease in sub-Saharan Africa (SSA) and some Caribbean and Indian Ocean islands [11,63-65]. Other tick species found on camels in our study include Hy. truncatum, Rh. camicasi and Rh. pulchellus; the latter two species were also found on sheep. Our report of Rh. camicasi infesting sheep and camels in northern Kenya extends knowledge about the geographic range and dynamics of this tick species in Kenya. Since most of these tick species have the potential to transmit diseases such as heartwater, anaplasmosis and $Q$ fever, domestic animals and humans in the region may be exposed to a variety of tick-borne diseases.

\subsection{Tick-Borne Bacteria Identified in Ticks, Camels and Co-Herded Sheep in Northern Kenya}

Our findings show that E. ruminantium, E. chaffeensis, "Ca. E. regneryi", C. burnetii, "Ca. A. camelii", A. ovis and T. ovis are circulating among ticks from camels and sheep in the study area. The findings also show occurrence of distinct TBPs, with some overlap, in blood and ticks from camels and sheep in the study area.

Ehrlichia ruminantium was detected in Am. gemma and Am. lepidum ticks sampled from both camels and co-herded sheep in this study and in sheep blood, but not in camel blood. The bacterium is known to infect macrophages, neutrophils and vascular endothelial cells of ruminant hosts and is a major cause of livestock loss in SSA [63]. The absence of the pathogen in blood samples is not surprising considering the fact that E. ruminantium is mainly found in endothelial cells and can only be rarely detected in the bloodstream, except during clinical heartwater $[66,67]$. Our finding of E. ruminantium, which causes heartwater disease in ruminants, in Amblyomma ticks feeding on camels supports the recent reports on their potential impact on SSA camel populations [18,68], although it remains unknown if camels are susceptible to infection with E. ruminantium. Our findings in combination with the identification of Ehrlichia sp. with a DNA sequence close to E. ruminantium in 
Moyale Constituency, which is part of the study area in 2016 [18], and the isolation of the pathogen from Amblyomma spp. in eight districts across Kenya [69] suggest that there is continuous circulation of E. ruminantium across the country. Since 2016 and during the entire study period in 2020, no clinical heartwater cases were reported from camels, sheep and goats in Marsabit (Boku Bodha, unpublished observations). This is an indication that E. ruminantium may be endemic in Marsabit County. However, there is lack of information on the role of camels in the epidemiology of ehrlichiosis.

Ehrlichia chaffeensis DNA was detected in Am. lepidum ticks from camels and in blood from sheep. Ehrlichia chaffeensis, an emerging TBP, is known to cause human monocytic ehrlichiosis in humans [70]. Recent studies have found E. chaffeensis in Haemaphysalis leachi ticks collected from dogs in Uganda [71], Rhipicephalus sanguineus from dogs in Cameroon [72], Amblyomma hebraeum collected from both cattle and sheep in South Africa [73] and questing Amblyomma eburneum ticks in Kenya [34], which suggests that diverse tick species may vector this pathogen. To our knowledge, this is the first detection of E. chaffeensis in Am. lepidum ticks collected from dromedary camels. Our finding of $E$. chaffeensis in Am. lepidum ticks collected from camels and in blood from co-grazing sheep in northern Kenya suggests that this pathogen is actively circulating in the study area. Further investigation on the epidemiology of this pathogen is required.

We detected "Ca. E, regneryi" in camel blood and in Hy. rufipes, Hy. dromedarii and $H y$. impeltatum ticks removed from camels, but not in other tick species feeding on camels. "Candidatus E. regneryi" is a novel Ehrlichia sp. first described in Saudi Arabia [74]. During an outbreak of heartwater-like disease in Moyale Constituency of Marsabit County in 2016, "Ca. E. regneryi" was found in blood from one camel that had reportedly recovered from the disease; however, the pathogen was not detected in ticks and blood from a severe clinical case of heartwater-like disease in a recumbent camel [18]. Our findings suggest that Hyalomma spp. are important vectors of the bacterium. "Candidatus E. regneryi" is phylogenetically closely related to Ehrlichia canis [74]. It is interesting to note that we did not detect the pathogen in blood and ticks from co-herded sheep, which suggests that it may be specific to camels. The pathogen was detected in apparently healthy camels, which suggests that the parasite in circulation is non-pathogenic and this is in line with the observations made in 2016 that the pathogen was not found in diseased camels [18]. Our findings suggest that camels are asymptomatic carriers of " $\mathrm{C} a$. E. regneryi" and further investigation into its pathogenicity, key vectors and zoonotic potential is required.

For $\mathrm{Q}$ fever, which is caused by C. burnetii, the association between camel exposure, seroprevalence in camels and human $Q$ fever infections is well documented from Chad [52], and a recent study in Somalia found that $C$. burnetii infections were common in camel ticks [75]. $Q$ fever is one of the most widespread neglected zoonosis worldwide with the highest seroprevalence rates recorded in female camels with a history of abortion [76]. Coxiella burnetii infection has been found in $\mathrm{Hy}$. dromedarii and $\mathrm{Hy}$. impeltatum ticks from camels in Tunisia [77]. While ticks facilitate a sylvan life cycle of $C$. burnetii in reservoir animals, domestic animals and humans are most commonly infected by contaminated aerosols [78]. We found C. burnetii in camel blood and in Hy. rufipes, Hy. dromedarii and Rh. pulchellus ticks from camels, which indicates that dromedary camels could be an additional reservoir species for this pathogen. In Laikipia, Kenya, just south of this study's geographic focus, $18.6 \%$ of camels have been found to have been exposed to C. burnetii by seropositivity [79]. The acute C. burnetii prevalence documented for healthy camels in this study $(3.4 \%)$ is comparable to the prevalence in clinically asymptomatic cattle (4.3\%) with a history of previous abortions and reproductive problems [80]. Coxiella burnetii is known to cause infections in a wide range of species, including domestic animals, birds and reptiles [29]. Ticks have been shown to transmit $C$. burnetii experimentally and could play a role as reservoirs in maintaining the bacterium in the environment between outbreaks due to their very long lives [81]. A study in Algeria suggested that Hyalomma spp. ticks could facilitate the transmission of $C$. burnetii among dromedary herds [51]. The detection of C. burnetii in Rhipicephalus and Hyalomma spp. corroborates previous reports on the same 
findings in Kenya [82-84] and Senegal [85]. Our results demonstrate that camels and their associated ticks in northern Kenya constitute an important epidemiological reservoir of $C$. burnetii, which increases human exposure and zoonotic risk of $\mathrm{Q}$ fever infection for camelkeeping communities, veterinarians and abattoir workers in the area. Antibodies against $C$. burnetii have been found in significant numbers of livestock handlers, indicating exposure to the pathogen $[86,87]$. Given the potential impact of $C$. burnetii on camel reproduction and the zoonotic risk for public health, further studies are required to better understand the role of camels in the epidemiology of $Q$ fever.

Coxiella endosymbionts were detected in Am. lepidum, Am. gemma and Rh. pulchellus ticks using Rickettsia 16S rRNA gene primers. To the best of our knowledge, this is the first study to register Coxiella endosymbionts in ticks collected from northern Kenya. Previous studies in Kenya have revealed the presence of Coxiella endosymbionts in ticks collected from Busia [37], the Maasai Mara National Reserve [36] and the coastal region [34]. Coxiella endosymbionts assist in blood meal processing and egg production by providing the tick host with essential micronutrients and macronutrients [88,89]. The roles of these Coxiella endosymbionts in ticks are still not clear and require further investigation. Coxiella burnetii and Coxiella endosymbionts have different transmission routes and infectiousness, even though they are closely related [81]. Understanding the role of Coxiella endosymbionts in ticks may advance our understanding of $Q$ fever.

We detected "Ca. A. camelii" in 78.7\% of blood samples from 233 apparently healthy camels, indicating presence of an asymptomatic healthy carrier state. This high prevalence of "Ca. A. camelii" was found in camels carrying Amblyomma ticks with E. ruminantium infection rates between $5.2 \%$ and $12.4 \%$. The fact that no heartwater cases were reported, observed or suspected in these camels throughout the study contradicts the notion that immunosuppression by " $\mathrm{C}$. A. camelii" may be a contributing factor in development of clinical heartwater-like disease in camels, a hypothesis which could not be ruled out entirely during the 2016 outbreak [18]. The present study corroborates previous findings of "Ca. A. camelii" in blood from healthy camels in Kenya $(6,18)$ and in other dromedary camel populations [53,90-92]. Carrier status or persistence in the host is an important strategy for successful pathogen transmission to ticks and for developing resistance against the reinfection of hosts [93]. The high prevalence of "Ca. A. camelii" in healthy camels is an indication of endemic stability and/or that the bacterium is non-pathogenic. We detected "Ca. A. camelii" in all eight tick species removed from these 233 camels, with infection rates in tick pools ranging from $2.7 \%$ to $8.5 \%$. We also detected " $\mathrm{C} a$. A. camelii" in one $R h$. camicasi tick collected from co-grazing sheep, but not in sheep blood. Interestingly, "Ca. A. camelii" has also been found in hippoboscid flies (Hippobosca camelina) collected from camels in northern Kenya [6]. These flies can transmit "Ca. A. camelii" to small laboratory animals [94], indicating that hippoboscids might also play a role in the transmission of this organism. High infection rates of $88.3 \%$ found for A. ovis in clinically healthy sheep blood during this study suggest that sheep in northern Kenya may serve as reservoirs for this pathogen. Although A. ovis infection is generally a subclinical infection in small ruminants, more severe infections resulting in significant economic losses have been reported in Spain [95].

We found high infection rates for R. africae in Am. gemma (10.9\%) and Am. lepidum (9.4\%) tick pools from camels and in Am. gemma (14.3\%) and Am. lepidum (16.7\%) tick pools from co-herded sheep. The detection of R. africae in Amblyomma ticks collected from camels and sheep points towards the importance of camel-associated and sheepassociated Amblyomma ticks as significant reservoirs of zoonotic R. africae in North Kenya. For R. aeschlimannii, the infection rates in camel tick pools were $4.8 \%$ for $R h$. pulchellus, $4.0 \%$ for $\mathrm{Hy}$. truncatum, $2.7 \%$ for $\mathrm{Hy}$. impeltatum, $1.1 \%$ for $\mathrm{Hy}$. rufipes and $0.33 \%$ for $H y$. dromedarii, respectively. These low infection rates suggest that camel-associated Hyalomma and Rhipicephalus spp. ticks represent minor reservoirs for R. aeschlimannii. Our findings correlate well with other studies that have predominantly detected R. africae in Amblyomma spp. and R. aeschlimannii in Hyalomma and Rhipicephalus spp. [59,60,96]. While 
R. africae and R. aeschlimannii were detected in both camels and their associated ticks in Algeria [97], we did not detect spotted fever group rickettsiae (SFGR) DNA in camel or sheep blood in the current study. The absence of SFGR may be due to the minute numbers of rickettsial organisms in the blood samples tested, the limited number of samples tested in this study or because the ticks are not actually transmitting the bacteria under normal circumstances. Camels in northern Kenya are kept close to homesteads and herds are in close association with other animals such as goats and sheep; thus, the presence of $R$. africae and $R$. aeschlimannii in ticks may present a health risk to humans. Healthcare providers in these areas should consider SFGR diseases in the differential diagnoses of patients presenting with fever of unknown origin and clinical signs compatible with rickettsioses.

We did not detect Theileria or Babesia spp. DNA in camel blood or in camel ticks. However, we did detect T. ovis in blood samples (80.5\%) and $R h$. camicasi ticks from healthy sheep. Similar high prevalence of T. ovis DNA in sheep blood has previously been reported in Ethiopia (91.9\%) [98] and Sudan (88.6\%) [99]; lower prevalences of 27-50\% in sheep in Ghana were based on the morphological identification of piroplasms in blood smears [100].

We also detected Paracoccus sp. in Ambylomma, Hyalomma and Rhipicephalus spp. collected from camels; this raises the possibility of these bacteria being transmitted or harboured by ticks or by another invertebrate organism parasitising ticks. These bacteria were first associated with ticks feeding on horses at a single site in Brazil [101] and subsequently in Kenya with Amblyomma spp. ticks collected from livestock and tortoises at a single sample site [59], as well as with questing Haemaphysalis concinna ticks at two sites in Hungary [102] and Rhipicephalus microplus ticks removed from a collared peccary in Peru [103]. Further investigation is required to elucidate the relationship between Paracoccus bacteria and ticks and whether they pose any risk to animal or human health.

\section{Conclusions}

This is the first study to show tick and TBP point prevalence and infection rates among Kenyan camel herds. We found that Hy. dromedarii and Hy. rufipes are the most prevalent tick species on camels in northern Kenya and that camels are exposed to a range of TBPs. We also report for the first time that $H y$. impeltatum ticks parasitise camels in Kenya. We report the presence of "Ca. E. regneryi", "Ca. Anaplasma camelii" and C. burnetii in camel blood and E. ruminantium, "Ca. E. regneryi", E. chaffeensis, "Ca. Anaplasma camelii", $R$. aeschlimannii, R. africae, C. burnetii and Coxiella endosymbionts in camel ticks in northern Kenya. Some of these pathogens, such as R. africae, E. chaffeensis and C. burnetii, are zoonotic and therefore have a potential to cause serious illness in humans. Presence of Coxiella endosymbionts in ticks raises exciting questions on the role they might play in tick physiology, population dynamics and the transmission of disease-causing pathogens. We found distinct TBPs, with some overlap, in blood and ticks from camels and sheep in the study area. These findings form a basis for strategic frameworks for research and development of novel control strategies, which are necessary to protect camels from threats that TBPs may pose. Further studies are required to identify the vectors of "Ca. E. regneryi" and "Ca. Anaplasma camelii" and for determining their effects on camel health and productivity. The epidemiology of E. ruminantium in camels needs to be investigated further to assess the potential involvement of this pathogen in heartwater-like disease of camels.

Supplementary Materials: The following are available online at https: / www.mdpi.com/article / 10.3390/microorganisms9071414/s1, Table S1: Morphological and molecular identification of tick samples collected from camels in Marsabit, northern Kenya, February-March 2020, Table S2: Minimum infection rates for TBPs identified in ticks and camel blood samples according to sampling sites in Marsabit, northern Kenya, February-March 2020, Table S3: Numbers of sampled camels and sheep with the same TBPs in ticks and blood or in ticks or blood only, Marsabit, northern Kenya, February-March 2020. 
Author Contributions: Conceptualization, J.L.B., E.K., M.Y., E.M.F., L.B.-S. and J.V.; methodology, D.G., J.L.B. and J.V.; validation, J.L.B. and J.V.; formal analysis, D.G, J.L.B. and J.V.; investigation, D.G., J.L.B., M.C., B.B., D.D., T.C. and J.V.; data curation, D.G. and J.V.; writing-original draft preparation, D.G.; writing-review and editing, J.L.B., E.K., M.C., N.G., M.Y., E.M.F., L.B.-S. and J.V.; visualization, D.G. and J.V.; supervision, J.L.B., E.K., M.C. and J.V.; project administration, J.L.B., E.K., E.M.F., L.B.-S. and J.V.; funding acquisition, J.L.B., E.K., N.G., M.Y., E.M.F., L.B.-S. and J.V. All authors have read and agreed to the published version of the manuscript.

Funding: This research received funding from the United Kingdom Biotechnology and Biological Sciences Research Council (BBSRC) Newton-Utafiti Fund project BB/S004890/1 and Kenya's National Research Fund (NRF) project NUF/ NRF-BBSRC CALL 1/1/02 "The role of heartwater (Ehrlichia ruminantium infection) and other tick-borne pathogens in Acute Camel Death Syndrome in Kenya" and fellowship support to Dennis Getange from Mpala Research Centre. Additionally, we acknowledge the icipe institutional funding from the UK's Foreign Commonwealth and Development Office (FCDO), the Swedish International Development Cooperation Agency (SIDA), the Swiss Agency for Development and Cooperation (SDC) and the Kenyan Government. J.L.B. is supported by DELTAS Africa Initiative grant \# DEL-15-011 to THRiVE-2. The DELTAS Africa Initiative is an independent funding scheme of the African Academy of Sciences (AAS)'s Alliance for Accelerating Excellence in Science in Africa (AESA) and supported by the New Partnership for Africa's Development Planning and Coordinating Agency (NEPAD Agency) with funding from the Welcome Trust grant \# 107742/Z/15/Z and the UK government. L.B.-S. is supported by the BBSRC grant BB/P024270/1. The funders had no role in design, data collection, interpretation or decision to submit this publication.

Institutional Review Board Statement: The study was conducted according to the guidelines of the Declaration of Helsinki, and approved by the University of Nairobi Biosafety, Animal Use and Ethics Committee (REF: FVM BAUEC/2019/200) and Kenya's National Commission for Science, Technology and Innovation (REF: NACOSTI/P/19/72855/27325).

Informed Consent Statement: Informed consent was obtained from all camel pastoralists whose herds were sampled.

Data Availability Statement: All nucleotide sequences generated in this study have been deposited in GenBank under the following accessions: MT896151-MT896154 (tick COI); MT895851-MT895865 (tick 12S rRNA); MT895169-MT89518116S (tick 16S rRNA); MT900489-MT900496, MW478135-MW478138 (Rickettsia spp.); MT900497-MT900501 (C. burnetii); MT929189-MT929192 (Ca. E. regneryi); MT929193MT929195, MW467546 (E. ruminantium); MT929188 (E. chaffeensis); MT929196-MT929197 (Ehrlichia sp.); MT929199-MT929201, MT929169-MT929177, MW690202 (Ca. A. camelii); MT929202 (Anaplasma sp.); MW541904-MW541911 (Coxiella endosymbionts); MW467555-MW467561 (T. ovis); and MW467547MW467552 (A. ovis).

Acknowledgments: We would like to thank Daniel Kairu, Daniel Mutwiri and James Kabii for their technical support, Milton Owido (ILRI) for his assistance in morphological identification of the ticks, Emily Kimathi (icipe) for her assistance in preparing the study map and the Marsabit County Veterinary Services Department staff and all camel owners and herdsmen who participated in the field sampling.

Conflicts of Interest: The authors declare no conflict of interest.

\section{References}

1. Kagunyu, A.W.; Wanjohi, J. Camel rearing replacing cattle production among the Borana community in Isiolo County of northern Kenya, as climate variability bites. Pastoralism 2014, 4, 13. [CrossRef]

2. FAOSTAT. Food and Agriculture Organization Statistical Database. 2016. Available online: http://www.fao.org/faostat/en/ \#data/QA (accessed on 5 December 2020).

3. Bornstein, S.; Younan, M. Significant veterinary research on the dromedary camels of Kenya: Past and present. J. Camelid Sci. 2013, 6, 1-48.

4. Khaskheli, A.A. A review on several important aspects of the camels. Aceh J. Anim. Sci. 2020, 5, 129-135. [CrossRef]

5. Abdisa, T.; Wubishet, Z.; Etsay, K. Study on major constraints of camel production, management and their impacts in and around Yabello District, Oromia Regional State, southern Ethiopia. J. Dairy Vet. Sci. 2017, 3, 555-604. [CrossRef] 
6. Kidambasi, K.O.; Masiga, D.K.; Villinger, J.; Carrington, M.; Bargul, J.L. Detection of blood pathogens in camels and their associated ectoparasitic camel biting keds, Hippobosca camelina: The potential application of keds in xenodiagnosis of camel haemopathogens. AAS Open Res. 2020, 2, 164. [CrossRef]

7. Getahun, M.N.; Villinger, J.; Bargul, J.L.; Orone, A.; Ngiela, J.; Ahuya, P.O.; Muema, J.M.; Saini, R.K.; Torto, B.; Masiga, D.K. Molecular characterization of pathogenic African trypanosomes in biting flies and camels in surra-endemic areas outside the tsetse fly belt in Kenya. bioRxiv 2020, 15, 68-69. [CrossRef]

8. Oguntomole, O.; Nwaeze, U.; Eremeeva, M. Tick-, flea-, and louse-borne diseases of public health and veterinary significance in Nigeria. Trop. Med. Infect. Dis. 2018, 3, 3. [CrossRef]

9. Kernif, T.; Leulmi, H.; Raoult, D.; Parola, P. Emerging tick-borne bacterial pathogens. Microbiol. Spectr. 2016, 4, EI10-0012-2016. [CrossRef]

10. Wesonga, F.D.; Kitala, P.M.; Gathuma, J.M.; Njenga, M.J.; Ngumi, P.N. An assessment of tick-borne diseases constraints to livestock production in a smallholder livestock production system in Machakos District, Kenya. Livest. Res. Rural Dev. 2010, $22,6$.

11. Jongejan, F.; Uilenberg, G. The global importance of ticks. Parasitology 2004, 129, S1-S4. [CrossRef]

12. Lwande, O.W.; Lutomiah, J.; Obanda, V.; Gakuya, F.; Mutisya, J.; Mulwa, F.; Michuki, G.; Chepkorir, E.; Fischer, A.; Venter, M.; et al. Isolation of tick and mosquito-borne arboviruses from ticks sampled from livestock and wild animal hosts in Ijara District, Kenya. Vector Borne Zoonotic Dis. 2013, 13, 637-642. [CrossRef]

13. Raboloko, O.O.; Ramabu, S.S.; Guerrini, L.; Jori, F. Seroprevalence of selected tick-borne pathogens and diversity and abundance of Ixodid ticks (Acari: Ixodidae) at the wildlife-livestock interface in northern Botswana. Front. Vet. Sci. 2020, 7, 187. [CrossRef]

14. Alsarraf, M.; Mierzejewska, E.J.; Mohallal, E.M.E.; Behnke, J.M.; Bajer, A. Genetic and phylogenetic analysis of the ticks from the Sinai Massif, Egypt, and their possible role in the transmission of Babesia behnkei. Exp. Appl. Acarol. 2017, 72, 415-427. [CrossRef]

15. Alanazi, A.D.; Nguyen, V.L.; Alyousif, M.S.; Manoj, R.R.S.; Alouffi, A.S.; Donato, R.; Sazmand, A.; Mendoza-Roldan, J.A.; Dantas-Torres, F.; Otranto, D. Ticks and associated pathogens in camels (Camelus dromedarius) from Riyadh Province, Saudi Arabia. Parasites Vectors 2020, 13, 110. [CrossRef]

16. Alanazi, A.D.; Al-Mohammed, H.I.; Alyousif, M.S.; Said, A.E.; Salim, B.; Abdel-Shafy, S.; Shaapan, R.M. Species diversity and seasonal distribution of hard ticks (Acari: Ixodidae) infesting mammalian hosts in various districts of Riyadh Province, Saudi Arabia. J. Med. Entomol. 2019, 56, 1027-1032. [CrossRef]

17. Dioli, M.; Jean-Baptiste, S.; Fox, M. Ticks (Acari: Ixodidae) of the one-humped camel (Camelus dromedarius) in Kenya and southern Ethiopia: Species composition, attachment sites. Rev. Elev. Med. Vet. Pays. Trop. 2001, 54, 115-122. [CrossRef]

18. Younan, M.; Ouso, D.O.; Bodha, B.; Keitany, E.K.; Wesonga, H.O.; Sitawa, R.; Kimutai, J.; Kuria, W.; Sake, W.S.; Svitek, N.; et al. Ehrlichia spp. close to Ehrlichia ruminantium, Ehrlichia canis, and "Candidatus Ehrlichia regneryi" linked to heartwater-like disease in Kenyan camels (Camelus dromedarius). Trop. Anim. Health Prod. 2021, 53, 147. [CrossRef]

19. van Vliet, A.H.M.; Zeijst, B.A.M.; Camus, E.; Mahan, S.M.; Martinez, D.; Jongejan, F. Use of a specific immunogenic region on the Cowdria ruminantium MAP1 protein in a serological assay. J. Clin. Microbiol. 1995, 33, 2405-2410. [CrossRef]

20. Bell-Sakyi, L.; Koney, E.B.M.; Dogbey, O.; Walker, A.R. Ehrlichia ruminantium seroprevalence in domestic ruminants in Ghana; I. Longitudinal survey in the Greater Accra region. Vet. Microbiol. 2004, 100, 175-188. [CrossRef]

21. County Government of Marsabit CIDP. County Government of Marsabit: First County Integrated Development Plan 2013-2017. 2013, p. 284. Available online: http:/ / www.kpda.or.ke/documents/CIDP/Marsabit.pdf (accessed on 29 March 2021).

22. Siciliano, G.; Bigi, V.; Vigna, I.; Comino, E.; Rosso, M.; Cristofori, E.; Demarchi, A.; Pezzoli, A. Comparison of multiple maximum and minimum temperature datasets at local level: The case study of North Horr sub-County, Kenya. Climate 2021, 9, 62. [CrossRef]

23. Walker, A.R.; Bouattour, A.; Camicas, J.; Estrada-Peña, A.; Horak, I.G.; Latif, A.A.; Pegram, R.G.; Preston, P.M. Ticks of Domestic Animals in Africa: A Guide to Identification of Tick Species; Bioscience Reports: Edinburgh, UK, 2003; p. 227.

24. Hebert, P.D.N.; Penton, E.H.; Burns, J.M.; Janzen, D.H.; Hallwachs, W. Ten species in one: DNA barcoding reveals cryptic species in the neotropical skipper butterfly Astraptes fulgerator. Proc. Natl. Acad. Sci. USA 2004, 101, 14812-14817. [CrossRef] [PubMed]

25. Sim on, C.; Frati, F.; Beckenbach, A.; Crespi, B.; Liu, H.; Flook, P. Evolution, weighting, and phylogenetic utility of mitochondrial gene sequences and a compilation of conserved polymerase chain reaction primers. Ann. Entomol. Soc. Am. 1994, 87, 651-701. [CrossRef]

26. Brahma, R.K.; Dixit, V.; Sangwan, A.K.; Doley, R. Identification and characterization of Rhipicephalus (Boophilus) microplus and Haemaphysalis bispinosa ticks (Acari: Ixodidae) of North East India by ITS2 and $16 \mathrm{~S}$ rDNA sequences and morphological analysis. Exp. Appl. Acarol. 2014, 62, 253-265. [CrossRef] [PubMed]

27. Nijhof, A.M.; Bodaan, C.; Postigo, M.; Nieuwenhuijs, H.; Opsteegh, M.; Franssen, L.; Jebbink, F.; Jongejan, F. Ticks and associated pathogens collected from domestic animals in the Netherlands. Vector-Borne Zoonotic Dis. 2007, 7, 585-595. [CrossRef]

28. Roux, V.; Raoult, D. Phylogenetic analysis of members of the genus Rickettsia using the gene encoding the outer-membrane protein rOmpB (ompB). Int. J. Syst. Evol. Microbiol. 2000, 50, 1449-1455. [CrossRef]

29. Hoover, T.A.; Vodkin, M.H.; Williams, J.C. A Coxiella burnetii repeated DNA element resembling a bacterial insertion sequence. J. Bacteriol. 1992, 174, 5540-5548. [CrossRef]

30. Tokarz, R.; Kapoor, V.; Samuel, J.E.; Bouyer, D.H.; Briese, T.; Lipkin, W.I. Detection of tick-borne pathogens by masstag polymerase chain reaction. Vector-Borne Zoonotic Dis. 2009, 9, 147-151. [CrossRef]

31. Goodman, J.L.; Nelson, C.; Vitale, B.; Madigan, J.E.; Dumler, J.S.; Kurtti, T.J.; Munderloh, U.G. Direct cultivation of the causative agent of human granulocytic ehrlichiosis. N. Engl. J. Med. 1996, 334, 209-215. [CrossRef] 
32. Parola, P.; Roux, V.; Camicas, J.L.; Baradji, I.; Brouqui, P.; Raoult, D. Detection of ehrlichiae in African ticks by polymerase chain reaction. Trans. R. Soc. Trop. Med. Hyg. 2000, 94, 707-708. [CrossRef]

33. Reysenbach, A.L.; Giver, L.J.; Wickham, G.S.; Pace, N.R. Differential amplification of rRNA genes by polymerase chain reaction. Appl. Environ. Microbiol. 1992, 58, 3417-3418. [CrossRef]

34. Mwamuye, M.M.; Kariuki, E.; Omondi, D.; Kabii, J.; Odongo, D.; Masiga, D.; Villinger, J. Novel Rickettsia and emergent tick-borne pathogens: A molecular survey of ticks and tick-borne pathogens in Shimba Hills National Reserve, Kenya. Ticks Tick Borne Dis. 2017, 8, 208-218. [CrossRef]

35. Gubbels, J.M.; De Vos, A.P.; Van Der Weide, M.; Viseras, J.; Schouls, L.M.; De Vries, E.; Jongejan, F. Simultaneous detection of bovine Theileria and Babesia species by reverse line blot hybridization. J. Clin. Microbiol. 1999, 37, 1782-1789. [CrossRef]

36. Oundo, J.W.; Villinger, J.; Jeneby, M.; Ong'amo, G.; Otiende, M.Y.; Makhulu, E.E.; Musa, A.A.; Ouso, D.O.; Wambua, L. Pathogens, endosymbionts, and blood-meal sources of host-seeking ticks in the fast-changing Maasai Mara wildlife eco-system. PLoS ONE 2020, 15, e0228366. [CrossRef]

37. Chiuya, T.; Masiga, D.K.; Falzon, L.C.; Bastos, A.D.S.; Fèvre, E.M.; Villinger, J. Tick-borne pathogens, including Crimean-Congo haemorrhagic fever virus, at livestock markets and slaughterhouses in western Kenya. Transbound. Emerg. Dis. 2020. Online ahead of print. [CrossRef]

38. Altschul, S.F.; Gish, W.; Miller, W.; Myers, E.W.; Lipman, D.J. Basic local alignment search tool. J. Mol. Biol. 1990, 215 , 403-410. [CrossRef]

39. Kearse, M.; Moir, R.; Wilson, A.; Stones-Havas, S.; Cheung, M.; Sturrock, S.; Buxton, S.; Cooper, A.; Markowitz, S.; Duran, C.; et al. Geneious Basic: An integrated and extendable desktop software platform for the organization and analysis of sequence data. Bioinformatics 2012, 28, 1647-1649. [CrossRef]

40. Guindon, S.; Dufayard, J.F.; Lefort, V.; Anisimova, M.; Hordijk, W.; Gascuel, O. New algorithms and methods to estimate maximum-likelihood phylogenies: Assessing the performance of PhyML 3.0. Syst. Biol. 2010, 59, 307-321. [CrossRef]

41. Rambaut, A. FigTree; Version 1.4.4; University of Edinburgh: Edinburgh, UK, 2020.

42. Okal, M.N.; Odhiambo, B.K.; Otieno, P.; Bargul, J.L.; Masiga, D.; Villinger, J.; Kalayou, S. Anaplasma and Theileria pathogens in cattle of Lambwe Valley, Kenya: A case for pro-active surveillance in the wildlife-Livestock interface. Microorganisms 2020, 8, 1830. [CrossRef]

43. Wikel, S.K. Ticks and tick-borne infections: Complex ecology, agents, and host interactions. Vet. Sci. 2018, 5, 60. [CrossRef]

44. Kanduma, E.G.; Mwacharo, J.M.; Mwaura, S.; Njuguna, J.N.; Nzuki, I.; Kinyanjui, P.W.; Githaka, N.; Heyne, H.; Hanotte, O.; Skilton, R.A.; et al. Multi-locus genotyping reveals absence of genetic structure in field populations of the brown ear tick (Rhipicephalus appendiculatus) in Kenya. Ticks Tick Borne Dis. 2016, 7, 26-35. [CrossRef]

45. Dantas-Torres, F.; Chomel, B.B.; Otranto, D. Ticks and tick-borne diseases: A One Health perspective. Trends Parasitol. 2012, 28, 437-446. [CrossRef]

46. Elghali, A.; Hassan, S.M. Ticks (Acari: Ixodidae) infesting camels (Camelus dromedarius) in northern Sudan. Onderstepoort J. Vet. Res. 2009, 76, 177-185. [CrossRef]

47. Youssef, S.Y.; Yasien, S.; Mousa, W.M.A.; Nasr, S.M.; El-Kelesh, E.A.M.; Mahran, K.M.; Abd-El-Rahman, A.H. Vector iden-tification and clinical, hematological, biochemical, and parasitological characteristics of camel (Camelus dromedarius) theileriosis in Egypt. Trop. Anim. Health Prod. 2015, 47, 649-656. [CrossRef]

48. Wallménius, K.; Barboutis, C.; Fransson, T.; Jaenson, T.G.; Lindgren, P.E.; Nyström, F.; Olsen, B.; Salaneck, E.; Nilsson, K. Spotted fever Rickettsia species in Hyalomma and Ixodes ticks infesting migratory birds in the European Mediterranean area. Parasites Vectors 2014, 7, 318. [CrossRef]

49. Kleinerman, G.; Baneth, G.; Mumcuoglu, K.Y.; Van Straten, M.; Berlin, D.; Apanaskevich, D.A.; Abdeen, Z.; Nasereddin, A.; Harrus, S. Molecular detection of Rickettsia africae, Rickettsia aeschlimannii, and Rickettsia sibirica mongolitimonae in camels and Hyalomma spp. ticks from Israel. Vector Borne Zoonotic Dis. 2013, 13, 851-856. [CrossRef]

50. Kernif, T.; Djerbouh, A.; Mediannikov, O.; Ayach, B.; Rolain, J.M.; Raoult, D.; Parola, P.; Bitam, I. Rickettsia africae in Hyalomma dromedarii ticks from sub-Saharan Algeria. Ticks Tick Borne Dis. 2012, 3, 377-379. [CrossRef]

51. Bellabidi, M.; Benaissa, M.H.; Bissati-Bouafia, S.; Harrat, Z.; Brahmi, K.; Kernif, T. Coxiella burnetii in camels (Camelus dromedarius) from Algeria: Seroprevalence, molecular characterization, and ticks (Acari: Ixodidae) vectors. Acta Trop. 2020, 206, 105443. [CrossRef] [PubMed]

52. Schelling, E.; Diguimbaye, C.; Daoud, S.; Nicolet, J.; Boerlin, P.; Tanner, M.; Zinsstag, J. Brucellosis and Q-fever seroprev-alences of nomadic pastoralists and their livestock in Chad. Prev. Vet. Med. 2003, 61, 279-293. [CrossRef]

53. Selmi, R.; Ben Said, M.; Dhibi, M.; Ben Yahia, H.; Messadi, L. Improving specific detection and updating phylogenetic data related to Anaplasma platys-like strains infecting camels (Camelus dromedarius) and their ticks. Ticks Tick Borne Dis. 2019, 10, 101260. [CrossRef] [PubMed]

54. Ghoneim, N.H.; Abdel-Moein, K.A.; Zaher, H.M. Molecular detection of Francisella spp. among ticks attached to camels in Egypt. Vector Borne Zoonotic Dis. 2017, 17, 384-387. [CrossRef] [PubMed]

55. Moshaverinia, A.; Moghaddas, E. Prevalence of tick infestation in dromedary camels (Camelus dromedarius) brought for slaughter in Mashhad abattoir, Iran. J. Parasit. Dis. 2015, 39, 452-455. [CrossRef] 
56. Rehman, A.; Nijhof, A.M.; Sauter-Louis, C.; Schauer, B.; Staubach, C.; Conraths, F.J. Distribution of ticks infesting ruminants and risk factors associated with high tick prevalence in livestock farms in the semi-arid and arid agro-ecological zones of Pakistan. Parasites Vectors 2017, 10, 190. [CrossRef]

57. Shemshad, M.; Shemshad, K.; Sedaghat, M.M.; Shokri, M.; Barmaki, A.; Baniardalani, M.; Rafinejad, J. First survey of hard ticks (Acari: Ixodidae) on cattle, sheep and goats in Boeen Zahra and Takistan counties, Iran. Asian Pac. J. Trop. Biomed. 2012, 2, 489-492. [CrossRef]

58. Chitimia-Dobler, L.; Schaper, S.; Rieß, R.; Bitterwolf, K.; Frangoulidis, D.; Bestehorn, M.; Springer, A.; Oehme, R.; Drehmann, M.; Lindau, A.; et al. Imported Hyalomma ticks in Germany in 2018. Parasites Vectors 2019, 12, 134. [CrossRef]

59. Omondi, D.; Masiga, D.K.; Fielding, B.C.; Kariuki, E.; Ajamma, Y.U.; Mwamuye, M.M.; Ouso, D.O.; Villinger, J. Molecular detection of tick-borne pathogen diversities in ticks from livestock and reptiles along the shores and adjacent islands of Lake Victoria and Lake Baringo, Kenya. Front. Vet. Sci. 2017, 4, 73. [CrossRef]

60. Kamani, J.; Baneth, G.; Mumcuoglu, K.Y.; Waziri, N.E.; Eyal, O.; Guthmann, Y.; Harrus, S. Molecular detection and characterization of tick-borne pathogens in dogs and ticks from Nigeria. PLoS Negl. Trop. Dis. 2013, 7, e2108. [CrossRef]

61. Kariuki, E.K.; Penzhorn, B.L.; Horak, I.G. Ticks (Acari: Ixodidae) infesting cattle and African buffaloes in the Tsavo conservation area, Kenya. Onderstepoort J. Vet. Res. 2012, 79, 437-441. [CrossRef]

62. Dohm, D.J.; Logan, T.M.; Linthicum, K.J.; Rossi, C.A.; Turell, M.J. Transmission of Crimean-Congo hemorrhagic fever virus by Hyalomma impeltatum (Acari: Ixodidae) after experimental infection. J. Med. Entomol. 1996, 33, 848-851. [CrossRef]

63. Allsopp, B.A. Heartwater-Ehrlichia ruminantium infection. Rev. Sci. Tech. 2015, 34, 557-568. [CrossRef]

64. Dumler, J.S.; Barbet, A.F.; Bekker, C.P.J.; Dasch, G.A.; Palmer, G.H.; Ray, S.C.; Rikihisa, Y.; Rurangirwa, F.R. Reorganization of genera in the families Rickettsiaceae and Anaplasmataceae in the order Rickettsiales: Unification of some species of Ehrlichia with Anaplasma, Cowdria with Ehrlichia and Ehrlichia with Neorickettsia, descriptions of six new species combi. Int. J. Syst. Evol. Microbiol. 2001, 51, 2145-2165. [CrossRef]

65. Walker, J.B.; Olwage, A. The tick vectors of Cowdria ruminantium (Ixodoidea, Ixodidae, genus Amblyomma) and their distribution. Onderstepoort J. Vet. Res. 1987, 54, 353-379. [PubMed]

66. Postigo, M.; Bell-Sakyi, L.; Paxton, E.; Sumption, K. Kinetics of experimental infection of sheep with Ehrlichia ruminantium cultivated in tick and mammalian cell lines. Exp. Appl. Acarol. 2002, 28, 187-193. [CrossRef] [PubMed]

67. Andrew, H.R.; Norval, R.A.I. The carrier status of sheep, cattle and African buffalo recovered from heartwater. Vet. Parasitol. 1989, 34, 261-266. [CrossRef]

68. Bechir, A. OIE Immediate Notification Report (31/12/2013). 2013. Available online: http://www.oie.int/wahis_2/public/wahid php/Reviewreport/Review?page_refer=MapFullEventReport\&reportid=14588 (accessed on 15 November 2020).

69. Ngumi, P.N.; Rumberia, R.M.; Williamson, S.M.; Sumption, K.J.; Lesan, A.C.; Kariuki, D.P. Isolation of the causative agent of heartwater (Cowdria ruminantium) from three Amblyomma species in eight districts of Kenya. Vet. Rec. 1997, 140, 13-16. [CrossRef]

70. Paddock, C.D.; Childs, J.E. Ehrlichia chaffeensis: A prototypical emerging pathogen. Clin. Microbiol. Rev. 2003, 16, 37-64. [CrossRef]

71. Proboste, T.; Kalema-Zikusoka, G.; Altet, L.; Solano-Gallego, L.; Fernández De Mera, I.G.; Chirife, A.D.; Muro, J.; Bach, E.; Piazza, A.; Cevidanes, A.; et al. Infection and exposure to vector-borne pathogens in rural dogs and their ticks, Uganda. Parasites Vectors 2015, 8, 306. [CrossRef]

72. Ndip, L.M.; Ndip, R.N.; Esemu, S.N.; Walker, D.H.; McBride, J.W. Predominance of Ehrlichia chaffeensis in Rhipicephalus sanguineus ticks from kennel-confined dogs in Limbe, Cameroon. Exp. Appl. Acarol. 2010, 50, 163-168. [CrossRef]

73. Iweriebor, B.C.; Mmbaga, E.J.; Adegborioye, A.; Igwaran, A.; Obi, L.C.; Okoh, A.I. Genetic profiling for Anaplasma and Ehrlichia species in ticks collected in the Eastern Cape Province of South Africa. BMC Microbiol. 2017, 17, 45. [CrossRef]

74. Bastos, A.D.S.; Mohammed, O.B.; Bennett, N.C.; Petevinos, C.; Alagaili, A.N. Molecular detection of novel Anaplasmataceae closely related to Anaplasma platys and Ehrlichia canis in the dromedary camel (Camelus dromedarius). Vet. Microbiol. 2015, 179, 310-314. [CrossRef]

75. Frangoulidis, D.; Kahlhofer, C.; Said, A.S.; Osman, A.Y.; Chitimia-Dobler, L.; Shuaib, Y.A. High prevalence and new genotype of Coxiella burnetii in ticks infesting camels in Somalia. Pathogens 2021, 10, 741. [CrossRef]

76. Devaux, C.A.; Osman, I.O.; Million, M.; Raoult, D. Coxiella burnetii in dromedary camels (Camelus dromedarius): A possible threat for humans and livestock in North Africa and the Near and Middle East? Front Vet Sci. 2020, 7, 558481. [CrossRef]

77. Selmi, R.; Ben Said, M.; Mamlouk, A.; Ben Yahia, H.; Messadi, L. Molecular detection and genetic characterization of the potentially pathogenic Coxiella burnetii and the endosymbiotic Candidatus Midichloria mitochondrii in ticks infesting camels (Camelus dromedarius) from Tunisia. Microb. Pathog. 2019, 136, 103655. [CrossRef]

78. Songer, J.G.; Post, K.W. Coxiella and Cowdria. In Veterinary Microbiology: Bacterial and Fungal Agents of Animal Disease, 1st ed.; Songer, J.G., Post, K.W., Eds.; Elsevier/Saunders: MO, USA, 2005; pp. 339-342.

79. Browne, A.S.; Fèvre, E.M.; Kinnaird, M.; Muloi, D.M.; Wang, C.A.; Larsen, P.S.; O’Brien, T.; Deem, S.L. Serosurvey of Coxiella burnetii (Q fever) in dromedary camels (Camelus dromedarius) in Laikipia County, Kenya. Zoonoses Public Health 2017, 64, 543-549. [CrossRef]

80. Kirkan, S.; Kaya, O.; Tekbiyik, S.; Parin, U. Detection of Coxiella burnetii in cattle by PCR. Turkish. J. Vet. Anim. Sci. 2008, 32, $215-220$.

81. Duron, O.; Sidi-Boumedine, K.; Rousset, E.; Moutailler, S.; Jourdain, E. The importance of ticks in Q Fever transmission: What has (and has not) been demonstrated? Trends Parasitol. 2015, 31, 536-552. [CrossRef] 
82. Knobel, D.L.; Maina, A.N.; Cutler, S.J.; Ogola, E.; Feikin, D.R.; Junghae, M.; Halliday, J.E.B.; Richards, J.L.; Breiman, R.S.; Cleaveland, S.; et al. Coxiella burnetii in humans, domestic ruminants, and ticks in rural Western Kenya. Am. J. Trop. Med. Hyg. 2013, 88, 513-518. [CrossRef]

83. Koka, H.; Sang, R.; Kutima, H.L.; Musila, L. Coxiella burnetii detected in tick samples from pastoral communities in Kenya. Biomed. Res. Int. 2018, 54, 774-780. [CrossRef]

84. Ndeereh, D.; Muchemi, G.; Thaiyah, A.; Otiende, M.; Angelone-Alasaad, S.; Jowers, M.J. Molecular survey of Coxiella burnetii in wildlife and ticks at wildlife-livestock interfaces in Kenya. Exp. Appl. Acarol. 2017, 72, 277-289. [CrossRef]

85. Mediannikov, O.; Fenollar, F.; Socolovschi, C.; Diatta, G.; Bassene, H.; Molez, J.F.; Sokhna, C.; Trape, J.-S.; Raoult, D. Coxiella burnetii in humans and ticks in rural Senegal. PLoS Negl. Trop. Dis. 2010, 4, e654. [CrossRef]

86. Neare, K.; Janson, M.; Hütt, P.; Lassen, B.; Viltrop, A. Coxiella burnetii antibody prevalence and risk factors of infection in the human population of Estonia. Microorganisms 2019, 7, 629. [CrossRef]

87. Szymańska-Czerwińska, M.; Galińska, E.M.; Niemczuk, K.; Knap, J.P. Prevalence of Coxiella burnetii infection in humans occupationally exposed to animals in Poland. Vector Borne Zoonotic Dis. 2015, 15, 261-267. [CrossRef]

88. Ben-Yosef, M.; Rot, A.; Mahagna, M.; Kapri, E.; Behar, A.; Gottlieb, Y. Coxiella-like endosymbiont of Rhipicephalus sanguineus is required for physiological processes during ontogeny. Front. Microbiol. 2020, 11, 493. [CrossRef]

89. Zhong, J.; Jasinskas, A.; Barbour, A.G. Antibiotic treatment of the tick vector Amblyomma americanum reduced reproductive fitness. PLoS ONE 2007, 2, e405. [CrossRef]

90. Belkahia, H.; Said, M.B.; Sayahi, L.; Alberti, A.; Messadi, L. Detection of novel strains genetically related to Anaplasma platys in Tunisian one-humped camels (Camelus dromedarius). J. Infect. Dev. Ctries. 2015, 9, 1117-1125. [CrossRef]

91. Azmat, M.; Ijaz, M.; Farooqi, S.H.; Ghaffar, A.; Ali, A.; Masud, A.; Saleem, S.; Rehman, A.; Ali, M.M.; Mehmood, K.; et al. Molecular epidemiology, associated risk factors, and phylogenetic analysis of anaplasmosis in camel. Microb. Pathog. 2018, 123, 377-384. [CrossRef]

92. Bahrami, S.; Hamidinejat, H.; Ganjali, A.R. First molecular detection of Anaplasma phagocytophilum in dromedaries (Camelus dromedarius). J. Zoo Wildl. Med. 2018, 49, 844-848. [CrossRef]

93. Brown, W.C. Adaptive immunity to Anaplasma pathogens and immune dysregulation: Implications for bacterial persistence. Comp. Immunol. Microbiol. Infect. Dis. 2012, 35, 241-252. [CrossRef]

94. Bargul, J.; Kidambasi, K.; Getahun, M.; Villinger, J.; Copeland, R.; Muema, J.; Carrington, M.; Masiga, D.K. Transmission of 'Candidatus Anaplasma camelii' to laboratory animals by camel-specific keds, Hippobosca camelina. PLOS Negl. Trop. Dis. 2021, in press.

95. Lacasta, D.; Ferrer, L.M.; Sanz, S.; Labanda, R.; González, J.M.; Benito, A.Á.; Ruiz, H.; Rodríguez-Largo, A.; Ramos, J.J. Anaplasmosis outbreak in lambs: First report causing carcass condemnation. Animals 2020, 10, 1851. [CrossRef] [PubMed]

96. Koka, H.; Sang, R.; Kutima, H.L.; Musila, L.; Macaluso, K. The detection of spotted fever group Rickettsia DNA in tick samples from pastoral communities in Kenya. J. Med. Entomol. 2017, 54, 774-780. [CrossRef] [PubMed]

97. Selmi, R.; Ben Said, M.; Ben Yahia, H.; Abdelaali, H.; Messadi, L. Molecular epidemiology and phylogeny of spotted fever group Rickettsia in camels (Camelus dromedarius) and their infesting ticks from Tunisia. Transbound. Emerg. Dis. 2019, 67, 733-744. [CrossRef]

98. Gebrekidan, H.; Hailu, A.; Kassahun, A.; Rohoušová, I.; Maia, C.; Talmi-Frank, D.; Warburg, A.; Baneth, G. Theileria infection in domestic ruminants in northern Ethiopia. Vet. Parasitol. 2014, 200, 31-38. [CrossRef]

99. El Imam, A.H.; Hassan, S.M.; Gameel, A.A.; Abdelrahim, M.; Hussein, E.; Taha, K.M.; Oosthuizen, M.C. Molecular identi-fication of different Theileria and Babesia species infecting sheep in Sudan. Polish Parasitol. Soc. 2016, 62, 47-54. [CrossRef]

100. Bell-Sakyi, L.; Koney, E.B.M.; Dogbey, O.; Walker, A.R. Incidence and prevalence of tick-borne haemoparasites in domestic ruminants in Ghana. Vet. Parasitol. 2004, 124, 25-42. [CrossRef]

101. Machado-Ferreira, E.; Piesman, J.; Zeidner, N.S.; Soares, C.A.G. A prevalent alpha-proteobacterium Paracoccus sp. in a population of the Cayenne ticks (Amblyomma cajennense) from Rio de Janeiro, Brazil. Genet. Mol. Biol. 2012, 35, 862-867. [CrossRef]

102. Egyed, L.; Makrai, L. Cultivable internal bacterial flora of ticks isolated in Hungary. Exp. Appl. Acarol. 2014, 63, 107-122. [CrossRef]

103. Rojas-Jaimes, J.; Lindo-Seminario, D.; Correa-Nunez, G.; Diringer, B. Characterization of the bacterial microbiome of Rhipicephalus (Boophilus) microplus collected from Pecari tajacu "Sajino" Madre de Dios, Peru. Sci. Rep. 2021, 11, 6661. [CrossRef] 